\title{
Zinc Plant Uptake as Result of Edaphic Factors Acting
}

\author{
Vyacheslav Sergeevich Anisimov* $*$, Lydia Nikolaevna Anisimova and Andrey Ivanovich Sanzharov
}

Russian Institute of Radiology and Agroecology 1, Kievskoe sh., 109th km, Kaluga Region, 249032 Obninsk, Russia; lanisimovan@list.ru (L.N.A.); ais_55@mail.ru (A.I.S.)

* Correspondence: vsanisimov@list.ru

Citation: Anisimov, V.S.; Anisimova, L.N.; Sanzharov, A.I. Zinc Plant Uptake as Result of Edaphic Factors Acting. Plants 2021, 10, 2496. https:// doi.org/10.3390/plants10112496

Academic Editor:

Gokhan Hacisalihoglu

Received: 25 October 2021

Accepted: 15 November 2021

Published: 18 November 2021

Publisher's Note: MDPI stays neutral with regard to jurisdictional claims in published maps and institutional affiliations.

Copyright: (c) 2021 by the authors. Licensee MDPI, Basel, Switzerland. This article is an open access article distributed under the terms and conditions of the Creative Commons Attribution (CC BY) license (https:// creativecommons.org/licenses/by/ $4.0 /)$.

\begin{abstract}
The influence of soil characteristics on the lability and bioavailability of zinc at both background and phytotoxic concentrations in Albic Retisol soil (Loamic, Ochric) was studied using various methods. Ranges of insufficient, non-phytotoxic, and phytotoxic zinc concentrations in soil solutions were established in an experiment with an aqueous barley culture. It was experimentally revealed that for a wide range of non-toxic concentrations of $\mathrm{Zn}$ in the soil corresponding to the indicative type of plant response, there was constancy of the concentration ratio $(C R)$ and concentration factor $(C F)$ migration parameters. As a result, a new method for assessing the buffer capacity of soils with respect to $\mathrm{Zn}\left(P B C_{\mathrm{Zn}}\right)$ is proposed. The transformation processes of the chemical forms and root uptake of native (natural) zinc contained in the Albic Retisol (Loamic, Ochric) through the aqueous culture of barley were studied using a cyclic lysimetric installation and radioactive ${ }^{65} \mathrm{Zn}$ tracer. The distribution patterns of $\mathrm{Zn}\left({ }^{65} \mathrm{Zn}\right)$ between different forms (chemical fractions) in the soil were established using the sequential fractionation scheme of BCR. The coefficients of distribution and concentration factors of natural $\mathrm{Zn}$ and ${ }^{65} \mathrm{Zn}$, as well as accumulation and removal of the metal by plants were estimated. The values of the enrichment factor of natural (stable) $\mathrm{Zn}$ contained in sequentially extracted chemical fractions with the ${ }^{65} \mathrm{Zn}$ radioisotope were determined and the amount of the pool of labile zinc compounds in the studied soil was calculated.
\end{abstract}

Keywords: zinc; ${ }^{65} \mathrm{Zn}$; soil; soil solution; barley; lability; specific activity; potential buffer capacity; forms; labile zinc pool

\section{Introduction}

Increases in the concentrations of heavy metals (HMs) in soils as a result of technogenic pollution lead to negative effects in agricultural ecosystems such as crop losses, deterioration in the quality of agricultural products, and decreases in soil microbiological activity. However, among a wide range of pollutants, Zn deserves special attention for a number of reasons

First of all, zinc is one of the 17 elements necessary for plants, with an average content of $0.002 \%$ (20 ppm) in dry vegetative mass [1]. At the same time, it is also an important trace element-zinc deficiency negatively affects the growth and maturation of plants $[1,2]$, which leads to crop losses and even, in the most severe cases, plant death. Zinc deficiency is often caused not only by the low metal content in the soil but also by the influence of the type of soil that determines its availability to plants. [2,3]. Thus, it was noted in [4] that Zn deficiency is observed in all soils with a low availability of Zn, which primarily include calcareous and highly phosphated soils with high $\mathrm{pH}$.

In general, about 50\% of the world's soils contain insufficient amounts of $\mathrm{Zn}$ [5]. Zn deficiency has been observed in significant amounts of soil in Bangladesh, Brazil, Pakistan, the Philippines, Sudan, sub-Saharan Africa, India, Turkey, Western Australia, and China, as well as on the Great Plains and in the western regions of the United States [2,6].

At the same time, zinc is the most common among heavy metals (HMs) polluting soil as a result of anthropogenic impact [1,7-10]. The most significant sources of pollution are the use of fertilizers and sewage sludge in agricultural practice, emissions and discharges 
from the mining and metallurgical industries, and road transport [11,12]. At high concentrations of zinc in the soil, various cytotoxic effects are manifested and lead to decreases in the biomass and yield of agricultural plants.

Thus, the study of zinc behavior in soils is of particular interest. In addition, due to its high mobility in soils and lack of ability to change the degree of oxidation in the environment, $\mathrm{Zn}$ is a convenient object for studying HM migration.

Zn's mobility in soils and availability to plants strongly depend on the ratio of the different forms (chemical fractions) of the element in soils [5,8,12,13].

To date, a large number of methods for determining the fractional composition of HMs in soils have been developed. All of them use specific reagents to isolate individual groups of HM compounds in soils (exchangeable, easily soluble, and associated with organo-mineral complex compounds, organic matter, carbonates, $\mathrm{Fe}, \mathrm{Mn}$ oxides, etc.). Using schemes of the sequential chemical fractionation of HMs $[4,10,14-23]$, it is possible to assess their lability and bioavailability, the distribution by fractions of the main groups of compounds and minerals in soils (exchange associated with oxides of $\mathrm{Al}, \mathrm{Fe}, \mathrm{Mn}$, carbonates, phosphates, sulfides, organic matter, and crystal matrixes of soil minerals), the lability and bioavailability of HMs under changing soil conditions $(\mathrm{pH}$, redox potential, humidity, salinity, etc.).

However, all of the above methods only allow researchers to solve the main task with a modest degree of approximation - to estimate the real pool of labile and bioavailable HM compounds. In fact, a more accurate solution of this problem is only possible when using the isotopic dilution method [11,23-28].

This method is based on the law of ideal isotope exchange [29] of ions of applied radioactive or stable isotopes acting as tracers and ions of native (stable) isotopes of the HMs under study in a soil-soil solution-plant system. The isotopic dilution method allows one to calculate the amount of reserves (pools) in the soil: (a) of the total number of labile compounds of the studied HM ("E-value" $\left.\left(E_{\mathrm{HM}}\right)\right)$ and (b) the total number of biologically available compounds of HM (" $L$-value" $\left.\left(L_{\mathrm{HM}}\right)\right)$.

Additionally, the isotopic dilution method, being a source of valuable data on the total amount of stocks (pools) of labile and biologically available HM compounds in soil, does not allow for the obtainment of information regarding potential lability in a soil-soil solution system and the bioavailability of various forms of HMs. To solve the abovementioned problem, it is necessary to apply an integrated approach, including the joint use of methods of isotopic dilution and subsequent fractionation of soil into which a stable or radioactive HM tracer has been previously introduced, followed by the analysis of isotope ratios for individual chemical fractions.

An important aspect of the problem of interaction of technogenic HMs (including $\mathrm{Zn}$ ) with soils is the latter's potential for the specific and non-specific sorption of heavy metals due to the presence of soil minerals, the high molecular weight organic compounds, occluding processes, co-deposition, and the action of other mechanisms. These processes lead to the immobilization of HMs in soils. Their total effect, which can be quantified, is manifested in the form of the buffer capacity of soils in relation to HMs [16,30-32].

The objectives of this work were:

(1) To clarify the issue with different models of plant behavior in conditions of $\mathrm{Zn}$ pollution and to evaluate the buffer capacity of the soil with respect to $\mathrm{Zn}$ using barley as a test plant.

(2) Determine the pool of labile compounds of native $\mathrm{Zn}$ using ${ }^{65} \mathrm{Zn}$ as a radioactive tracer and assess the potential lability and bioavailability of individual forms of the metal in the soil under conditions as close as possible to equilibrium. For this purpose, a special flow lysimetric installation of cyclic action was developed and tested in practice. 


\section{Results and Discussion}

\subsection{Experiment I}

The studied Albic Retisol (Loamic, Ochric) soil was found to be coarsely textured, poor in available potassium, weakly acidic, contained a small amount of organic carbon, and had a low cation exchange capacity. However, the content of biologically available phosphorus was found to be high (the consequences of the abundant phosphating of agricultural land during the Soviet era). As such, it was an infertile low buffer soil that was not located in the best natural conditions.

More interesting is the behavior of zinc-one of the most important trace elements for living organisms and the most common pollutant -when it enters soil in increased quantities [33].

Before the experiment, a total content of zinc in the soil were determined in the samples (Table 1).Because the soil did not contain carbonates, the results obtained for the exchange of $\mathrm{Ca}^{2+}$ and $\mathrm{Mg}^{2+}\left(5.20 \pm 0.06\right.$ and $0.40 \pm 0.09 \mathrm{cmol}(+) \mathrm{kg}^{-1}$, respectively) with the use of AAB-4.8 as an extractant did not significantly differ from the results obtained using neutral salts as extractants: $1 \mathrm{M} \mathrm{NH}_{4} \mathrm{Cl}\left(5.70 \pm 0.68\right.$ and $\left.0.53 \pm 0.05 \mathrm{cmol}(+) \mathrm{kg}^{-1}\right)$ and AAB-7.0 $\left(5.21 \pm 0.08\right.$ and $\left.0.47 \pm 0.10 \mathrm{cmol}(+) \mathrm{kg}^{-1}\right)$. Therefore, extraction with AAB-4.8 was used to estimate the total pool of exchange (non-specific bound) forms of alkali, alkaline earth elements and zinc. In addition, the exchange forms of HMs extracted by AAB-4.8 from soils in the extracting solution were capable of forming weak complexes of $\mathrm{HM}(\mathrm{Ac})_{\mathrm{n}}$ that prevented the hydrolysis and re-deposition of metals [32].

Table 1. Main characteristics of Albic Retisol (Loamic, Ochric) soil (mean \pm standard deviation).

\begin{tabular}{|c|c|}
\hline Parameter & Value \\
\hline \multicolumn{2}{|l|}{ Mass fraction of particles $(\mathrm{mm})$ in soil, $\%$} \\
\hline $1-0.25$ & 35.08 \\
\hline $0.25-0.05$ & 15.64 \\
\hline $0.05-0.01$ & 30.88 \\
\hline $0.01-0.005$ & 5.20 \\
\hline $0.005-0.001$ & 7.30 \\
\hline$<0.002$ & 8.75 \\
\hline$<0.001$ & 5.89 \\
\hline \multicolumn{2}{|l|}{ Exchangeable cation content, cmol (+) $\mathrm{kg}^{-1}$} \\
\hline $\mathrm{Ca}^{2+}$ & $5.20 \pm 0.06$ \\
\hline $\mathrm{Mg}^{2+}$ & $0.40 \pm 0.09$ \\
\hline $\mathrm{K}^{+}$ & $0.15 \pm 0.01$ \\
\hline $\mathrm{pH}$ & $5.05 \pm 0.01$ \\
\hline $\mathrm{pH}_{\text {water }}$ & $6.04 \pm 0.01$ \\
\hline $\mathrm{C}_{\mathrm{org}}, \%$ & $1.0 \pm 0.01$ \\
\hline Total acidity (TA), $\mathrm{cmol}(+) \mathrm{kg}^{-1}$ soil & $1.89 \pm 0.02$ \\
\hline Total exchangeable bases (S), $\mathrm{cmol}^{(+)} \mathrm{kg}^{-1}$ & $5.3 \pm 0.2$ \\
\hline Labile $\mathrm{P}_{2} \mathrm{O}_{5}, \mathrm{mg} \mathrm{kg}^{-1}$ (Kirsanov method) & $126.9 \pm 1.9$ \\
\hline Mass fraction of total $\mathrm{Zn}$ in native soil, $\mathrm{mg} \mathrm{kg}^{-1}$ & $37.1 \pm 2.8$ \\
\hline
\end{tabular}

Extraction using the same reagent to obtain non-specifically related compounds of various macro- and microelements was convenient in practical terms and created conditions for the in-depth study of the relationship between links in the soil-soil solution-plant migration chain. In addition, the validity of the determination of non-specifically bound (exchange) forms of HMs in soils by extracting them with neutral salt solutions at $\mathrm{pH} 7.0$ is doubtful due to the tendency of multicharged transition element cations to hydrolyze with repeated precipitation [32,34].

The mass fraction of "labile" forms of zinc in the studied soil linearly increased with the amount of metal introduced (Figure 1). At the same time, the relative content of the labile form of $\mathrm{Zn}$ with the amount of metal introduced into the soil non-linearly increased in accordance with a power dependence. Thus, in the native soil, the proportion of "labile 
(or accessible to plants)" Zn from the total metal content was equal to 33\%. With increases in the dose of $\mathrm{Zn}$ introduced into the soil, the proportion of its "labile" forms from the total amount of metal in the soil increased to $75 \%$.

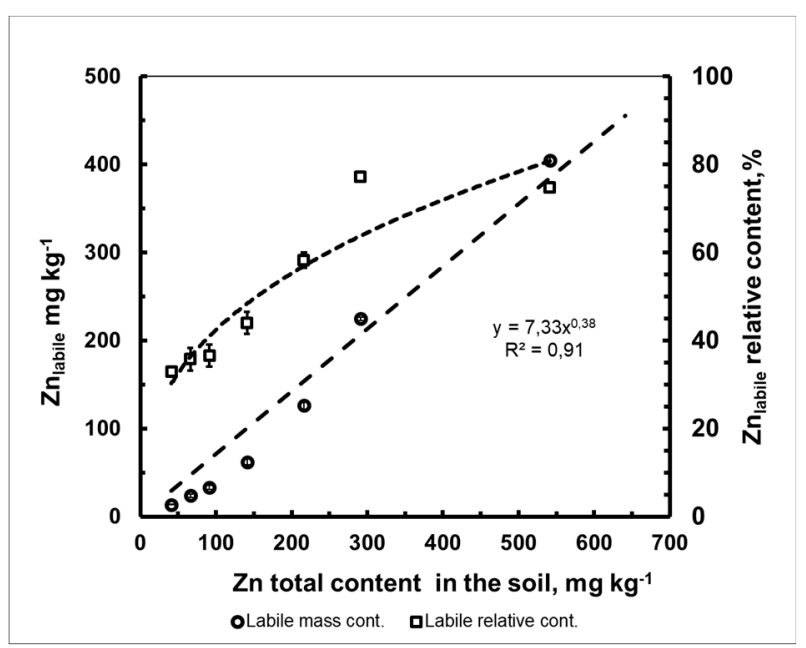

Figure 1. The change in the content of the labile form of $\mathrm{Zn}$ in Albic Retisol (Loamic, Ochric) soil (mean value \pm standard deviation; $n=3$ ). Data are from the vegetation experiment $\mathrm{I}$.

The study of the features of Zn migration in the soil-barley system under the conditions of a vegetative experiment with increasing amounts of introduced $\mathrm{Zn}$ is important for the purposes of predicting the behavior of metals in agroecosystems, e.g., in the case of technogenic contamination with metal in a water-soluble form. With the help of such experiments, it was possible for us to obtain a general picture of the concentration dependence of $[\mathrm{Zn}]_{\text {plant }}=\mathrm{f}[\mathrm{Zn}]_{\text {soil }}$ without investigating the essence of the involved migration mechanisms. In our case, the obtained dependence of zinc accumulation in barley straw on the total amount of metal in the soil presented the form of a straight line in a wide range of metal concentrations in the soil from 38 to $538 \mathrm{mg} \mathrm{kg}^{-1}$, with a proportionality coefficient,

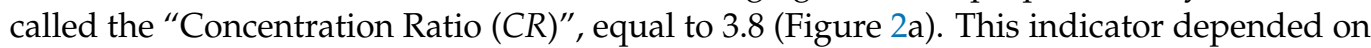
both the properties of the soil and the individual characteristics of zinc uptake by plants.

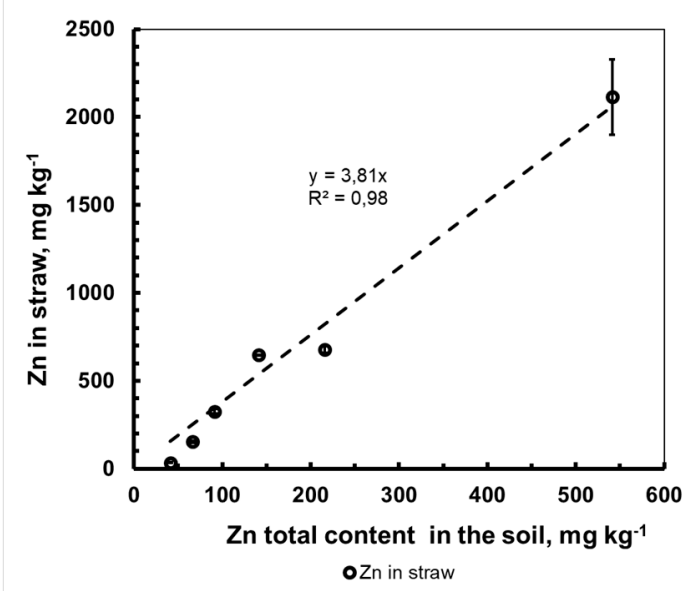

(a)

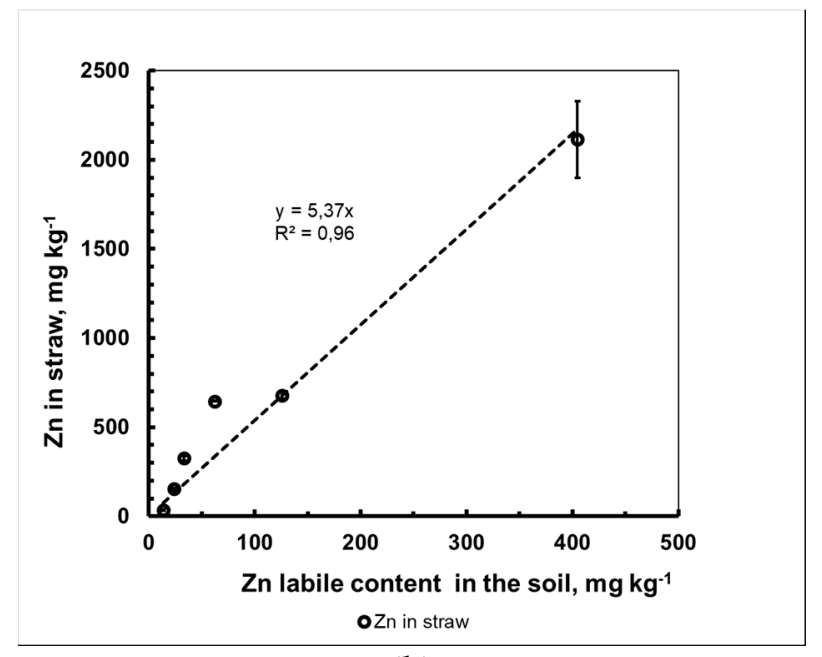

(b)

Figure 2. Dependence of the mass concentration of $\mathrm{Zn}$ in barley straw on the total amount (a) and labile form (b) of the metal in the soil (mean value \pm standard deviation; $n=3$ ). 
So why does the $[\mathrm{Zn}]_{\text {plant }}=\mathrm{f}[\mathrm{Zn}]_{\text {soil }}$ dependence present a straightforward character? This was firstly due to the rectilinear nature of the dependence $[\mathrm{Zn}]_{\text {soil, labile }}=\mathrm{f}[\mathrm{Zn}]_{\text {soil,total }}$, $\left(R^{2}=0.98\right)$ (Figure 1$)$ and secondly to the universal nature of the biological mechanisms of $\mathrm{Zn}$ absorption involved in a wide range of non-toxic metal concentrations in the soil. The relationship between the accumulation level Zn (and any other HMs) in the plant and its content in the soil can be considered a response of the plant. If there is a directly proportional relationship between the metal content in the soil and its accumulation in the biomass of plants, then this type of response is called "indicative" [35]. Attention is drawn to the fact that the concentration range of zinc is large, even in the low-fertility and low-buffer soil under study.

Figure $2 \mathrm{~b}$ shows the dependence of the concentration of $\mathrm{Zn}$ in barley straw on the content of metal in the labile form in the soil. This relationship was found to be directly proportional, although slightly less pronounced than the previous case $\left(C R_{Z n}\right.$,labile $\left.=5.4, R^{2}=0.96\right)$. Studying the dependence of $[\mathrm{Zn}]_{\text {plant }}=\mathrm{f}[\mathrm{Zn}]_{\text {soil, labile }}$ allowed us to more objectively assess the contribution of other soil characteristics (such as $\mathrm{pH}$ and cationic composition) to the migration ability of HMs based only on the content of labile form of the metal in different soils. This was due to the fact that part of labile form $(\alpha)$ of the total soil metal content, as shown in the $[\mathrm{Zn}]_{\text {soil, labile }}=\alpha[\mathrm{Zn}]_{\text {soil,total }}$ expression, can differ for different soils many times with the same amount of $[\mathrm{Zn}]_{\text {soil,total }}$ and, accordingly, make an additional contribution to the overall variance of the $[\mathrm{Zn}]_{\text {plant }}$ dependent variable.

The $[\mathrm{Zn}]_{\text {grain }}=\mathrm{f}[\mathrm{Zn}]_{\text {soil,total }}$ and $[\mathrm{Zn}]_{\text {grain }}=\mathrm{f}[\mathrm{Zn}]_{\text {soil,labile }}$ dependencies presented, respectively, in Figure $3 a, b$, were obviously non-linear. They were satisfactorily approximated by a power function. The presence of such a dependence indicates the involvement of different mechanisms during the translocation of $\mathrm{Zn}$ from vegetative mass into the economically valuable part of the crop-grain. In addition, at a $250 \mathrm{mg} \mathrm{kg}^{-1}$ dose of introduced zinc $\left(\mathrm{Zn}_{250}\right)$, grain formation did not occur, and at a dose of $\mathrm{Zn}_{500}$, even the development of generative organs was not observed and the plants themselves did not survive to the phase of the beginning of earing.

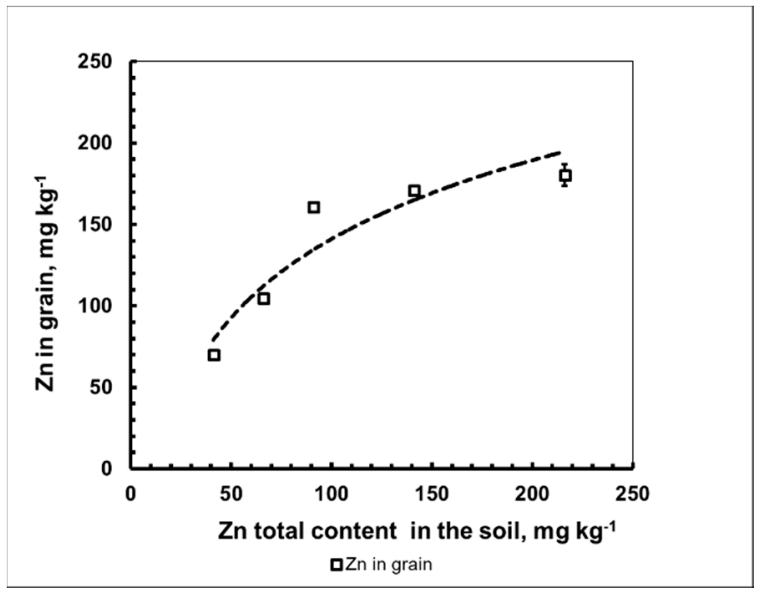

(a)

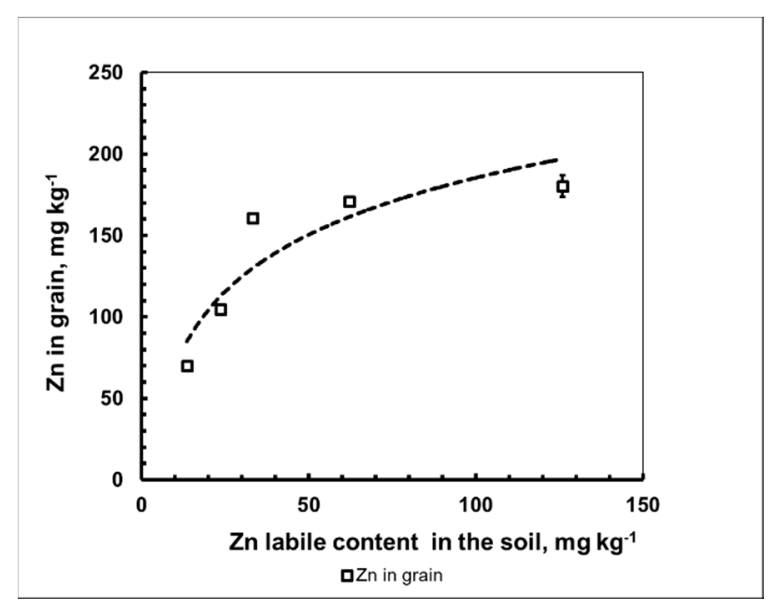

(b)

Figure 3. Dependence of the mass concentration of $\mathrm{Zn}$ in barley grain on the total amount (a) and labile form content (b) of the metal in the soil (mean value \pm standard deviation; $n=3$ ).

The concentration dependence between the amount of the labile form of $\mathrm{Zn}$ in the soil and the content of $\mathrm{Zn}$ in the phytomass of barley was most clearly demonstrated by the data obtained for relatively young 21-day-old plants (Figure 4a,b). The dependences were found to be directly proportional, and their angular coefficients $\left(C R_{Z n}\right)$ were equal to 4.02 and 5.68, respectively; although these were close to the values shown in Figure 2 for straw, they were still 5-10\% more, which indicated a slight decrease in the concentration of $\mathrm{Zn}$ in the straw compared to the dry biomass of the 21-day-old plants. Perhaps this was 
due to the effect of the "biological dilution" of $\mathrm{Zn}$ in the vegetative mass of barley in the phenophases following the tillering phase (21 days) and with leaf litter at maturity.

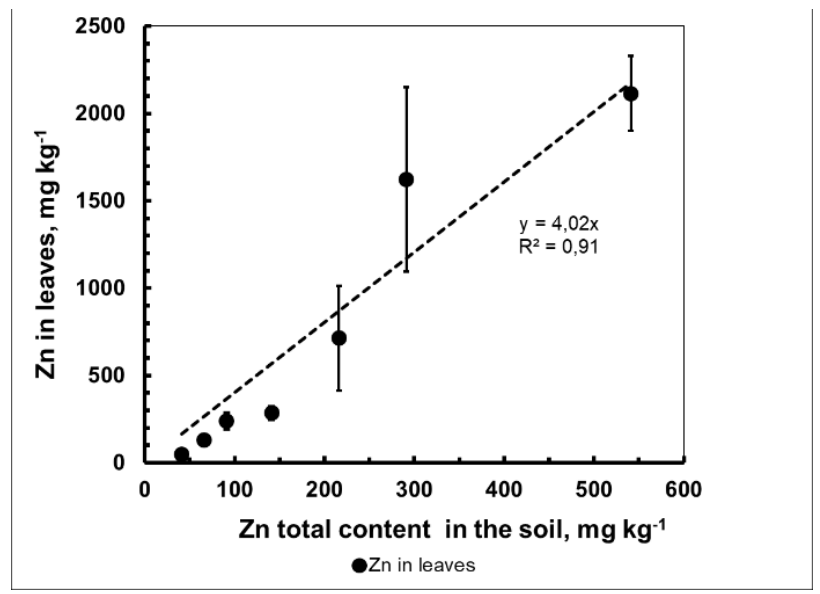

(a)

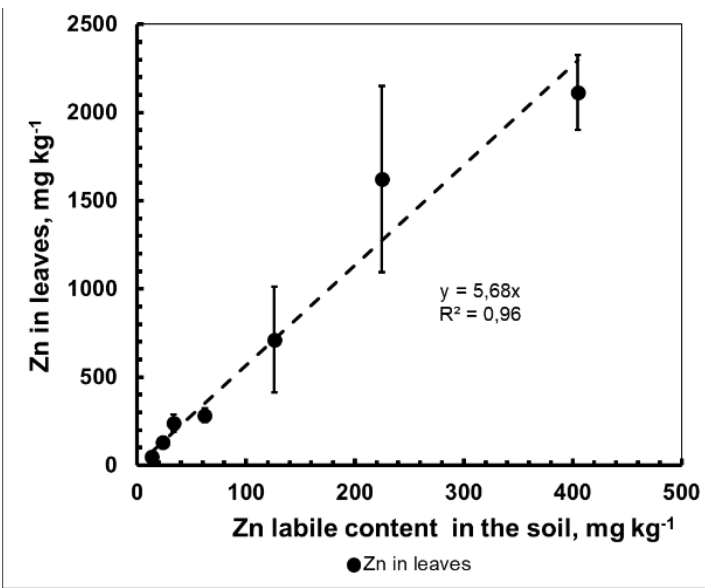

(b)

Figure 4. Dependence of the mass concentration of $\mathrm{Zn}$ in the phytomass of 21-day-old barley plants on the total amount (a) and labile form (b) of the metal in the soil (mean value \pm standard deviation; $n=3$ ).

Knowing the patterns of $\mathrm{Zn}$ behavior in the soil-plant system in a wide range of concentrations provided us to an effective tool for predicting the accumulation of metal in agricultural products under conditions of technogenic pollution. However, without a detailed study of the liquid phase of the soil-soil solution, knowledge of the role of various mechanisms in the accumulation of HMs by plants will be incomplete. Thus, due to the almost ubiquitous increased content of $\mathrm{Zn}$ in soil due to technogenesis, the "zero" point (without introducing Zn) in experiments with native agricultural soils will most likely be in the area of sufficient concentrations with an indicative type of plant response. In this case, it will not be possible to establish the patterns of $\mathrm{Zn}$ behavior in low concentrations zones, where the accumulative type of plant response is formed. Nutrient solutions representing an aqueous extract from the corresponding soils are ideal for clarifying migration patterns in areas of low concentrations of $\mathrm{Zn}$ in long-term vegetation experiments.

\subsection{Experiment II}

Vegetation experiments with a water culture of barley were carried out for a fairly long period of time-21 days. As a nutrient solution, a soil solution extracted from the studied soil was used with a narrow soil:solution ratio $=1: 2$. Increasing amounts of $\mathrm{Zn}\left(\mathrm{NO}_{3}\right)_{2}$ were added to various soil solution batches. No additional nutritious elements were added to the solution, except for a small amount of nitrogen in the form of $\mathrm{Ca}\left(\mathrm{NO}_{3}\right)_{2}$ (based on $0.2 \mathrm{mM} \mathrm{N}\left(\mathrm{NO}_{3}{ }^{-}\right)$) due to the need to adjust the nitrate content according to each variant with a $\mathrm{Zn}$ concentration of $114 \mu \mathrm{mol} \mathrm{L}^{-1}$ (the metal concentration of $430 \mu \mathrm{mol} \mathrm{L}^{-1}$ turned out to be highly phytotoxic). The obtained results regarding the accumulation of zinc in plant roots and phytomass are presented in the form of a diagram in Figure 5 a.

It is obvious that with a relatively low concentration of zinc in the soil solution $\left(<5.84 \times 10^{-3} \mathrm{mM}\right)$, an accumulative type of plant response to the metal content was observed, characteristic of the lack of an element [35]. With a similar type of plant response, the kinetic curve of metal accumulation by roots from a nutrient solution (obtained using the water culture method) was satisfactorily described by a function resembling the power-law $y=a \times x^{1 / 2}$ in appearance but representing a superposition of two functions: asymptotic, described by the Michaelis-Menten enzymatic catalysis equation [36], and linear [6,37,38]. Moreover, the role of the latter was found to increase with increases in the concentration of $\mathrm{Zn}$ in the solution. This indicated the dominance of at least two transmembrane transfer systems in the region of very low and low concentrations of $\mathrm{Zn}$ in the substrate, differing in the degree of affinity to metal and using both highly specific carrier proteins with respect 
to Zn, mainly ZIP family, and other less specific ones, the number of which is limited in the cell $[1,37,39]$. Due to its participation in the process of the transmembrane transfer of metal into the roots of highly specific carrier proteins, we found an increased accumulation of $\mathrm{Zn}$ compared to the amount of metal that the plant would be able to assimilate as a result of electrochemical diffusion processes. The linear component was primarily due to the absorption of metal ions by plant apoplast and electrochemical diffusion [37,40].
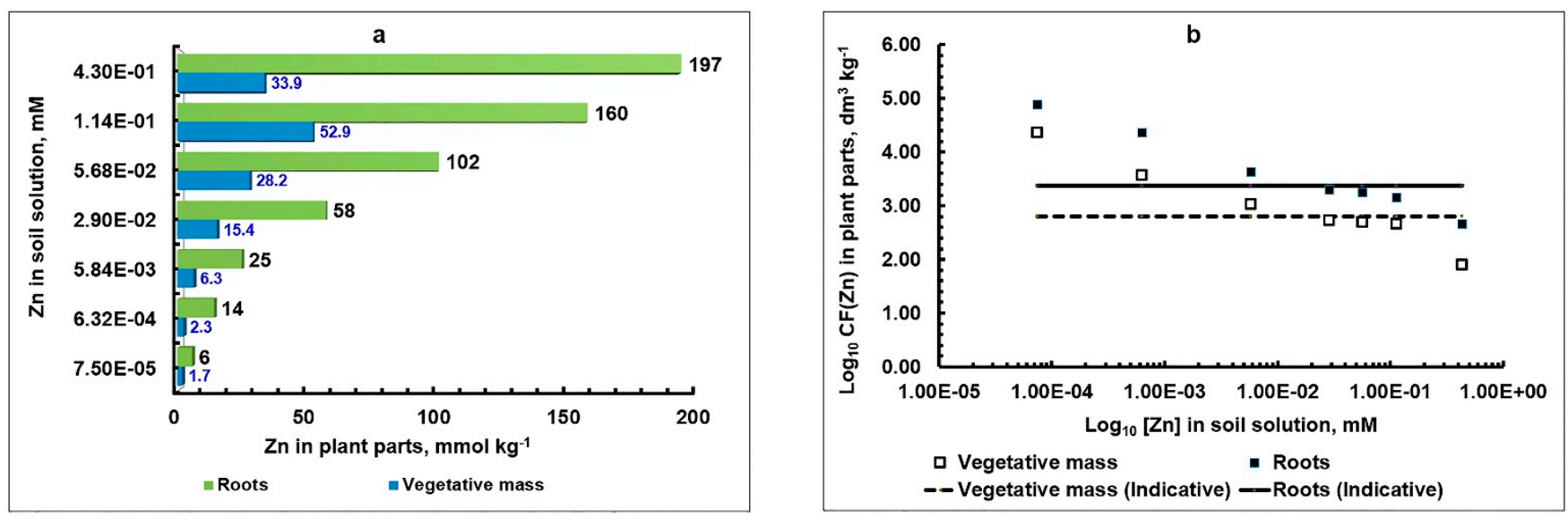

Figure 5. The relationship between the concentration of $\mathrm{Zn}$ in the soil solution and its content in different parts of 21-day-old barley plants (in terms of dry biomass) (a); values of $C F_{Z n, \text { roots }}$ and $C F_{Z n, \mathrm{VPs}}$, expressed for clarity in logarithmic form (b). Straight lines denote constant values in the "indicative" region $C F_{Z n, \text { roots }}=2375$ and $C F_{Z n, \mathrm{VPs}}=640 \mathrm{dm}^{3} \mathrm{~kg}^{-1}$.

Corresponding to the specified range of $\mathrm{Zn}$ concentrations in the soil solution, the ranges of its concentrations in barley vegetative and root phytomass were found to be $1.7 \div 6.3$ and $6 \div 25 \mathrm{mmol} \mathrm{kg}^{-1}$ of dry mass, respectively.

At higher concentrations of $\mathrm{Zn}$ in a soil solution, in the range from $5.84 \times 10^{-3}$ to $1.14 \times 10^{-1} \mathrm{mM}$, the processes of the non-specific transmembrane transport of $\mathrm{Zn}$ ions entering the root surface begin to prevail as a result of a convective moisture flow and electrochemical diffusion processes $[1,7,40]$ and the absorption of metal ions by apoplast. In our case, it can be argued that this range coincided with the range of non-toxic (normal, or optimal $[35,41])$ concentrations of $\mathrm{Zn}$ in the soil solution. As already mentioned, this type of plant response is called "indicative" (there is a directly proportional relationship between the metal content in the substrate and its accumulation in the biomass of plants). Corresponding to the specified range of $\mathrm{Zn}$ concentrations in the soil solution, the ranges of its concentrations in the VPs and roots of barley were $6.3 \div 52.9$ and $25 \div 160 \mathrm{mmol}$ $\mathrm{kg}^{-1}$ of dry mass, respectively, and the values of the corresponding constant coefficients of proportionality, called "Concentration Factors $(C F)$ ", were equal to $C F_{Z n \text {,roots }}=2375$ and $C F_{Z n, \mathrm{VPs}}=640 \mathrm{~L} \mathrm{~kg}^{-1}$, respectively $\left(C F_{Z n}=[\mathrm{Zn}]_{\text {plant }} /[\mathrm{Zn}]_{\text {soil solution }}\right)$ (Figure $\left.5 \mathrm{~b}\right)$.

Finally, in the area of high concentrations of $\mathrm{Zn}$ in the soil solution $\left(1.14 \times 10^{-1} \mathrm{mM}\right.$ $\div 4.30 \times 10^{-1} \mathrm{mM}$ ), the phytotoxicity of $\mathrm{Zn}$ for barley was manifested. In this case, the physiological mechanisms regulating the uptake and translocation of $\mathrm{Zn}$ in plants were seriously disrupted. The type of plant response could be characterized as barrier restrictive [35]. At the same time, there was a strong oppression of barley plants and their premature death.

Accordingly, it should be noted that the abovementioned indicative type of plant response [35] in relation to zinc is the most common in real conditions with man-made soil contamination via metal.

\subsection{Assessment of Zn Mobility in the Soil-Plant System and Determination of the Inactivating (Buffering) Ability of the Soil in Case of Contamination}

As already mentioned, the migration ability of $\mathrm{Zn}$ in a soil-plant system is influenced by biological factors related to the physiological characteristics of plants $[8,39,41-45]$, as 
well as the edaphic factors that determine the inactivating ability or buffering of soils in relation to $\mathrm{Zn}$ and other pollutants $[34,35,40]$.

In the case of an indicative type of plant response, for example, for the aboveground biomass of 21-day-old barley plants (Figure $4 \mathrm{~b}$ ), a simple ratio will be observed:

$$
d[\mathrm{Zn}]_{\text {plant }} / d[\mathrm{Zn}]_{\text {exch }}=[\mathrm{Zn}]_{\text {plant }} /[\mathrm{Zn}]_{\text {exch }}=C R_{\mathrm{Zn}, \text { exch }}=\mathrm{const}
$$

and (Figure 5)

$$
d[\mathrm{Zn}]_{\text {plant }} / d[\mathrm{Zn}]_{\text {soil solution }}=[\mathrm{Zn}]_{\text {plant }} /[\mathrm{Zn}]_{\text {soil solution }}=C F_{\mathrm{Zn}}=\text { const }
$$

where $[\mathrm{Zn}]_{\text {plant }}$ is the mass (or molar) fraction of HMs in the dry aboveground biomass of the plant and $C R_{\mathrm{Zn} \text {,labile }}$ is the concentration ratio of HMs in the plant in terms of the mass (or molar) content of its "labile (available to plants)" form in the soil. As follows from Figure $4 \mathrm{~b}$, the value of $C R_{\mathrm{Zn} \text {,exch }}$ was equal to the tangent of the slope angle of the linear section of the above dependence: 5.68 .

Earlier [34,46], we proposed a methodological approach for assessing the inactivating ability of soils with respect to HMs in conditions of technogenic pollution by using test plants. It was based on the fact that plants are essentially a universal integrating link in the soil-plant migration chains of different HMs. First of all, they uptake these metals for a long time and from a sufficiently large soil volume; secondly, they demonstrate similar patterns of behavior in conditions of HM pollution. The applied pollutant was zinc. Since then, this approach has undergone some corrections and additions. Its current version is presented below.

According to the definition given in [31] (p. 34), "the buffering of the system of compounds of microelements of the soil horizon in relation to any chemical element is understood as the ability to maintain the level of concentration of the element in the soil solution of this horizon at a constant level when the element level changes from the outside."

As a measure of the potential buffering capacity $(P B C)$ of soils in relation to a chemical element (for example, potassium), F. Beckett [47] proposed the use of the quotient between the change in the concentration of an exchange-sorbed element in the soil $(Q$, capacity factor) and the activity of the cations of the element under study in a quasi-equilibrium extracting (soil) solution $a_{\mathrm{Me}}$, normalized for the total activity of macronutrient cations $a_{\mathrm{Ca}+\mathrm{Mg}}(I$, intensity factor) in a wide range of concentrations of the element in the soil, with the exception of extremely low concentrations at which deviations from the law of ion exchange are observed. In a formal form, a similar dependence for $\mathrm{Zn}^{2+}$ ions can be written as the following equation:

$$
P B C_{\mathrm{Zn}}=\frac{Q}{I}=\frac{\Delta[\mathrm{Zn}]_{\mathrm{exch}}}{\Delta A R}
$$

where $\Delta[\mathrm{Zn}]_{\text {exch }}$ is the amount of metal in the exchangeably sorbed state that the soil absorbed from the equilibration solution or, conversely, gave into the equilibration solution in comparison to the initial content of exchangeably sorbed $\mathrm{Zn}$ in the soil; $\triangle A R$ is the ratio of the activities of the cations of the metal under study $\left(a_{\mathrm{Zn}}\right)$ and the cations of the macroelements $\mathrm{Ca}^{2+}$ and $\mathrm{Mg}^{2+}\left(a_{\mathrm{Ca}+\mathrm{Mg}}\right)$ in a quasi-equilibrium soil solution at different concentrations of $\mathrm{Zn}$ in this solution. In the graphical representation of the dependence $\triangle A R-\Delta[\mathrm{Zn}]_{\text {exch, }}$ the tangent of the slope angle of the linear part of the obtained dependence characterizes $P B C_{\mathrm{Zn}}$.

Equation (3) follows from the law of acting masses for exchanging cations in the system cation exchange complex (CEC) - a quasi-equilibrium soil solution. Thus, the equivalent exchange of divalent zinc cations on negatively charged surfaces of soil particles for $\mathrm{Ca}^{2+}$ and $\mathrm{Mg}^{2+}$ cations (which in a sum of about $90 \%$ of the exchange positions in CEC [48]) can be expressed using the following exchange reaction equation:

$$
[\mathrm{Ca}+\mathrm{Mg}]_{\text {exch }}+\left[\mathrm{Zn}^{2+}\right] \leftrightarrow[\mathrm{Zn}]_{\text {exch }}+\left[\mathrm{Ca}^{2+}+\mathrm{Mg}^{2+}\right]
$$


where $[\mathrm{Ca}+\mathrm{Mg}]_{\text {exch }}$ and $[\mathrm{Zn}]_{\text {exch }}$ are the exchange cations in the composition of $\mathrm{CEC}, \mathrm{mmol} \mathrm{kg}^{-1}$ (determined using AAB-4.8 before the negative reaction to $\mathrm{Ca}^{2+}$ ions); $\left[\mathrm{Ca}^{2+}+\mathrm{Mg}^{2+}\right]$, and $\left[\mathrm{Zn}^{2+}\right]$ are the same cations in the composition of the soil solution, $\mathrm{mM}$. The proposal to collectively consider $\mathrm{Ca}^{2+}$ and $\mathrm{Mg}^{2+}$ ions in the soil-soil solution system as cations of the same type, denoting them with the symbol of the predominant Ca cation, was formulated by Beckett $[49,50]$ with reference to the studies of other authors and their own previously obtained results.

Accordingly, the ratio of exchanging cations in the CEC phase and the soil solution can be expressed using Equation (5). The form of this equation shown below reflects the fact that in the case of an equivalent exchange-for example, $\mathrm{Zn} /(\mathrm{Ca}+\mathrm{Mg})-A R=$ $A R_{\mathrm{Zn},(\mathrm{Ca}+\mathrm{Mg})}=\left[\mathrm{Zn}^{2+}\right] /\left[\mathrm{Ca}^{2+}+\mathrm{Mg}^{2+}\right]:$

$$
\frac{[\mathrm{Zn}]_{\text {exch }, i}}{[\mathrm{Ca}+\mathrm{Mg}]_{\text {exch }, i}}=K_{\mathrm{Zn},(\mathrm{Ca}+\mathrm{Mg})}^{S} \frac{\left[\mathrm{Zn}^{2+}\right]_{i}}{\left[\mathrm{Ca}^{2+}+\mathrm{Mg}^{2+}\right]_{i}}
$$

where $i=1$ or 2 is the index characterizing the state of the system, $a_{\mathrm{Ca}+\mathrm{Mg}}$ is the total activity in a quasi-equilibrium soil solution of $\mathrm{Ca}^{2+}+\mathrm{Mg}^{2+}$ ions, and $a_{\mathrm{Zn}}$ is the activity of $\mathrm{Zn}^{2+}$ ions. If we express the concentrations of exchange-bound $Z n$ in the soil for states " 1 " and " 2 " through Equation (5), then the change in the amount of the corresponding metal form in the CEC can be described using the following equation:

$$
[\mathrm{Zn}]_{\mathrm{exch}, 1}-[\mathrm{Zn}]_{\mathrm{exch}, 2}=K_{\mathrm{Zn},(\mathrm{Ca}+\mathrm{Mg})}^{\mathrm{S}} \times\left(A R_{2} \times[\mathrm{Ca}+\mathrm{Mg}]_{\mathrm{exch}, 2}-A R_{1} \times[\mathrm{Ca}+\mathrm{Mg}]_{\mathrm{exch}, 1}\right)
$$

Or, due to the low loading of the CEC with $\mathrm{Zn}^{2+}$ ions, it can be expressed as:

$[\mathrm{Ca}+\mathrm{Mg}]_{\mathrm{exch}, 1} \approx[\mathrm{Ca}+\mathrm{Mg}]_{\mathrm{exch}, 2}=[\mathrm{Ca}+\mathrm{Mg}]_{\text {exch }}$ obtain:

$$
\Delta[\mathrm{Zn}]_{\mathrm{exch}}=K_{\mathrm{Zn},(\mathrm{Ca}+\mathrm{Mg})}^{S} \times[\mathrm{Ca}+\mathrm{Mg}]_{\mathrm{exch}} \times \Delta A R
$$

Or, introducing the designation $P B C_{\mathrm{Zn}}=K_{\mathrm{Zn},(\mathrm{Ca}+\mathrm{Mg})}^{S} \times[\mathrm{Ca}+\mathrm{Mg}]_{\mathrm{exch}}$, it can be expressed as:

$$
\Delta[\mathrm{Zn}]_{\text {exch }}=P B C_{\mathrm{Zn}} \times \triangle A R
$$

Considering Expressions (5), (7), and (8), the potential buffering capacity of the soil for the linear part of the ion exchange sorption isotherm of $\mathrm{Zn}$ can be expressed as the following expressions:

$$
\begin{gathered}
P B C_{\mathrm{Zn}}=K_{\mathrm{Zn},(\mathrm{Ca}+\mathrm{Mg})}^{S} \times[\mathrm{Ca}+\mathrm{Mg}]_{\text {exch }} \\
P B C_{\mathrm{Zn}}=\frac{[\mathrm{Zn}]_{\text {exch }}}{A R_{\mathrm{Zn},(\mathrm{Ca}+\mathrm{Mg})}} \\
P B C_{\mathrm{Zn}}=\frac{[\mathrm{Zn}]_{\mathrm{exch}}}{\left[\mathrm{Zn}^{2+}\right] /\left[\mathrm{Ca}^{2+}+\mathrm{Mga}^{2+}\right]} \\
P B C_{\mathrm{Zn}}=[\mathrm{Ca}+\mathrm{Mg}]_{\text {exch }} \times \frac{K_{d, \text { exch }}(\mathrm{Zn})}{K_{d, \text { exch }}(\mathrm{Ca}+\mathrm{Mg})}
\end{gathered}
$$

where $K_{d, \text { exch }}(\mathrm{Zn})=[\mathrm{Zn}]_{\text {exch }} /[\mathrm{Zn}]_{\text {soil solution }}$ and $K_{d, \text { exch }}(\mathrm{Ca}+\mathrm{Mg})=[\mathrm{Ca}+\mathrm{Mg}]_{\text {exch }} /\left[\mathrm{Ca}^{2+}+\right.$ $\left.\mathrm{Mg}^{2+}\right]_{\text {soil solution, }}$ which represent the distribution coefficients of $\mathrm{Zn}^{2+}$ and $\left(\mathrm{Ca}^{2+}+\mathrm{Mg}^{2+}\right)$, respectively, between the exchange form in the soil $\left(\mathrm{mmol} \mathrm{kg}^{-1}\right)$ and quasi-equilibrium soil solution $(\mathrm{mM})$.

It follows that the above conclusions would be correct if the load of CEC with $\mathrm{Zn}^{2+}$ ions is higher than $1 \%$. In this case, highly selective CEC sorption sites with respect to zinc ions will be completely blocked, and low-selective sites will remain available for ion exchange sorption, [51]. At the same time, the CEC loading of the studied cation should not exceed 5-10\% (according to F. Beckett [50]). If the above conditions are met, the following 
would be observed: $K^{S} \mathrm{Zn},(\mathrm{Ca}+\mathrm{Mg})=$ const, where $K^{\mathrm{S}} \mathrm{Zn},(\mathrm{Ca}+\mathrm{Mg})$ is the selectivity coefficient of ion exchange $\mathrm{Zn}^{2+} /\left(\mathrm{Ca}^{2+}+\mathrm{Mg}^{2+}\right)[52,53]$. The specified range was determined using the ion exchange equilibrium method and amounted to $0.5-19.6 \%$ of the total CEC of the studied soil. The average value of $K^{S} \mathrm{Zn},(\mathrm{Ca}+\mathrm{Mg})$ was equal to $13.5 \pm 6.6$. It should also be noted that the range of non-toxic concentrations of zinc in the soil fully fit into this range of CEC loadings, which corresponded to the indicative uptake of $\mathrm{Zn}$ by barley.

Considering that in the range of non-toxic concentrations of $\mathrm{Zn}$ in the soil and, accordingly, the soil solution, the values of $C R_{\mathrm{Zn}, \text { exch }}=[\mathrm{Zn}]_{\text {plant }} /[\mathrm{Zn}]_{\text {exch }}$ and $C F_{Z n}=[\mathrm{Zn}]_{\text {plant }} /[\mathrm{Zn}]_{\text {soil solution }}$ were found to be constant, so we substituted them in the $K_{d, \text { exch }}(\mathrm{Zn})$ parameter in Equation (12).

We also considered that for VPs (indicator part of barley plants):

- $C R_{(\mathrm{Ca}+\mathrm{Mg}) \text {,exch }}=$ const (because of the constant concentration of $\mathrm{Ca}$ and $\mathrm{Mg}$ in the soils, which have been applied with the increasing doses of $\mathrm{Zn}$, i.e., $[\mathrm{Ca}+\mathrm{Mg}]_{\text {exch }}=$ const $=$ $\left.23.7 \pm 4.4 \mathrm{mmol} \mathrm{kg}^{-1}\right)$.

- $C F_{(\mathrm{Ca}+\mathrm{Mg})}=$ const (because the concentrations of $\mathrm{Ca}^{2+}$ and $\mathrm{Mg}^{2+}$ in the soil solution with an increasing concentration of $\mathrm{Zn}^{2+}$ was not changed, and the $[\mathrm{Ca}+\mathrm{Mg}]_{\text {plant }} /\left[\mathrm{Ca}^{2+}+\right.$ $\left.\mathrm{Mg}^{2+}\right]_{\text {soil solution }}$ ratio remained constant in the experiment with the water culture of barley. It was found to be equal to $266 \pm 91 \mathrm{dm}^{3} \mathrm{~kg}^{-1}$.

Based on these arguments, we express the parameters $K_{d, \text { exch }}(\mathrm{Zn})$ and $K_{d, \text { exch }}(\mathrm{Ca}+\mathrm{Mg})$ through the parameters $C R_{\mathrm{Zn}, \mathrm{exch}}, C R_{(\mathrm{Ca}+\mathrm{Mg}), \text { exch }}, C F_{\mathrm{Zn}}$, and $C F_{(\mathrm{Ca}+\mathrm{Mg})}$ in Equation (12).

We obtained the final form of the equation for calculating the potential buffer capacity of soils with respect to technogenic Zn:

$$
P B C(V)_{\mathrm{Zn}}=[\mathrm{Ca}+\mathrm{Mg}]_{\text {exch }} \times \frac{C F_{\mathrm{Zn}} \times C R_{(\mathrm{Ca}+\mathrm{Mg}) \text {,exch }}}{C F_{(\mathrm{Ca}+\mathrm{Mg})} \times C R_{\mathrm{Zn}, \text { exch }}}
$$

With the help of this equation while knowing the parameters $C F_{\mathrm{Zn}}$ and $C F_{(\mathrm{Ca}+\mathrm{Mg})}$ for a specific agricultural crop (they can be obtained from experiments with water crops), it is easy to calculate the values of the potential buffer capacity of any soil with respect to zinc, for example, from agroecological examination materials in agricultural lands where amounts of $\mathrm{Ca}, \mathrm{Mg}$, and $\mathrm{Zn}$ in soil (exchangeable form) and conjugate plant samples have been determined.

Thus, considering the sum of green leaves and stems as indicator part of barley plants, we obtained the following results of experiments I and II (Table 2).

Table 2. The determined values of the parameters used to calculate $P B C(V)_{\mathrm{Zn}}$ (according to experiments 1 and 2).

\begin{tabular}{|c|c|}
\hline Parameter & Value \\
\hline \multicolumn{2}{|l|}{ Experiment I } \\
\hline$[\mathrm{Ca}+\mathrm{Mg}]_{\mathrm{VPs}}, \mathrm{mmol} \mathrm{kg}^{-1}$ & $526 \pm 9$ \\
\hline$[\mathrm{Ca}+\mathrm{Mg}]_{\text {exch }}, \mathrm{mmol} \mathrm{kg}^{-1}$ & $23.7 \pm 4.4$ \\
\hline$C R_{(\mathrm{Ca}+\mathrm{Mg}), \text { exch }}$ & 22.2 \\
\hline$C R_{\mathrm{Zn}, \text { exch }}$ & 5.68 \\
\hline \multicolumn{2}{|l|}{ Experiment II } \\
\hline$[\mathrm{Ca}+\mathrm{Mg}]_{\mathrm{VPs}}, \mathrm{mmol} \mathrm{kg}^{-1}$ & $613 \pm 197$ \\
\hline$\left[\mathrm{Ca}^{2+}+\mathrm{Mg}^{2+}\right]_{\text {soil solution, }} \mathrm{mM}$ & $1.81 \pm 0.26$ \\
\hline$C F_{(\mathrm{Ca}+\mathrm{Mg})}, \mathrm{dm}^{3} \mathrm{~kg}^{-1}$ & 339 \\
\hline$C F_{\mathrm{Zn}} \mathrm{dm}^{3} \mathrm{~kg}^{-1}$ & 640 \\
\hline
\end{tabular}

After substituting the values of the corresponding parameters into Equation (13), we obtained the value of $P B C(V)_{Z n}$ for the studied Albic Retisol (Loamic, Ochric) soil:

$P B C(V)_{\mathrm{Zn}}=[\mathrm{Ca}+\mathrm{Mg}]_{\text {exch }} \times\left(C F_{\mathrm{Zn}} \times C R_{(\mathrm{Ca}+\mathrm{Mg})}\right.$, exch $) /\left(C R_{\mathrm{Zn}, \text { exch }} \times C F_{(\mathrm{Ca}+\mathrm{Mg})}\right)=23.7 \times(640 \times 22.2) /(5.68 \times 339)=175 \mathrm{mmol} \mathrm{kg}^{-1}$ 
Thus, using $C F_{\mathrm{Me}(\mathrm{VPs})},(\mathrm{Me}=\mathrm{Ca}+\mathrm{Mg}, \mathrm{Zn})$ with values established in experiments with aquatic crops of agricultural plants, it is possible to quantify the buffering capacity of soils based on data on the content of a "labile (accessible to plants)" forms of $\mathrm{Zn}$ in these soils and the metal concentrations in the vegetative mass of plants.

In parallel, the $P B C_{Z n}$ of the studied Albic Retisol (Loamic, Ochric) soil was determined with the classical ion exchange equilibrium method under static conditions using a modification of the Beckett method [47-50]. In this method, the concentration of the macronutrient cation- $-\mathrm{Ca}^{2+}$ in the balancing solution, with an increase in the amount of the dissolved metal under study ( $\mathrm{Zn}$ in our case)—remained unchanged and equal to $2 \mathrm{mM}$ (20 mM in the Beckett method), which is close to the concentration of the macronutrient cation in the free (gravity) soil solution of the humus horizons of most soils. The value of $P B C_{\mathrm{Zn}}$ was determined to be $150 \mathrm{mmol} \mathrm{kg}{ }^{-1}$. This value was comparable to the $P B C(V)_{\mathrm{Zn}}$ value, obtained using test plants, despite the fundamental difference between the two methods (the relative difference was $15 \%$ ).

\subsection{Experiment III}

During the vegetation experiment with a flow lysimeter, it was found that the decrease in the concentration of stable $\mathrm{Zn}$ and the volumetric activity density of ${ }^{65} \mathrm{Zn}$ in the soil solution before and after the vegetation vessels over time was satisfactorily described by a power function with a negative indicator of the type $[\mathrm{Zn}]_{\text {soil solution }}=a \times t^{b}$, where $\boldsymbol{a}$ and $\boldsymbol{b}$ are parameters and $t$ is time in days (Figure 6a,b).
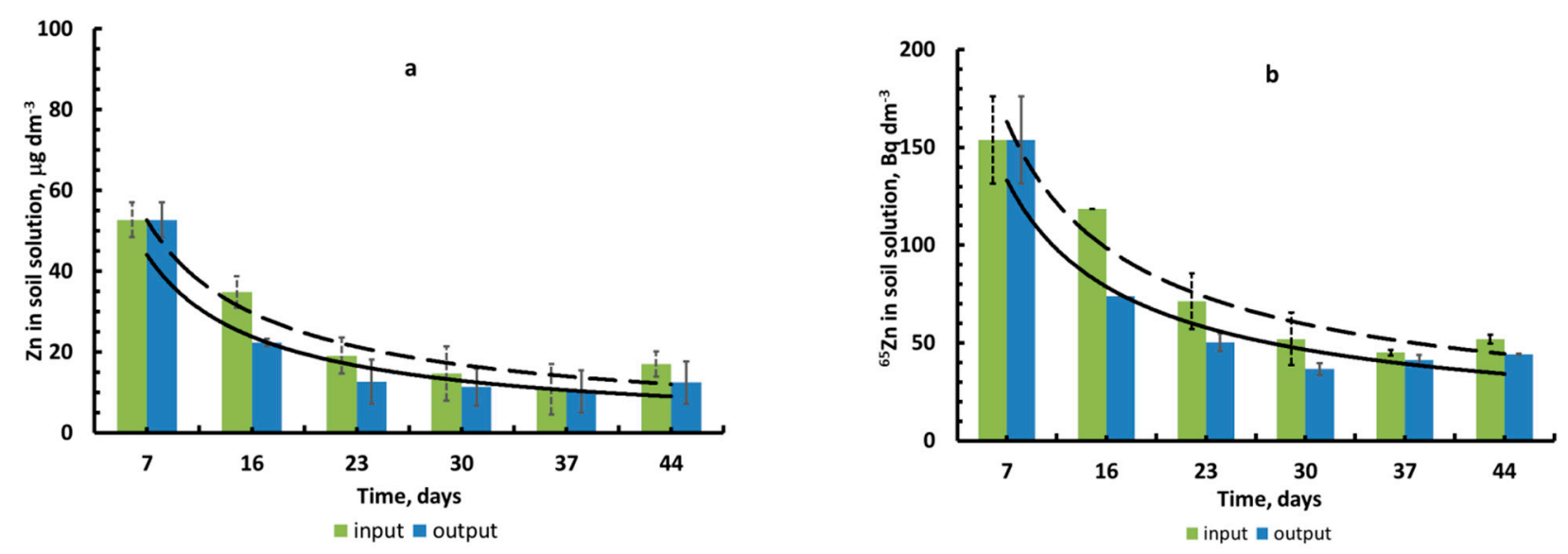

Figure 6. Experimental data for the soil solution in $[\mathrm{Zn}]_{\text {stable }}$ in $\mu \mathrm{g} \mathrm{dm}{ }^{-3}$ (a); volumetric activity density $\left({ }^{65} \mathrm{Zn}\right)$ in Bq dm ${ }^{-3}$ (b) (mean value \pm standard deviation; $n=3$ ).

The values of parameters $\boldsymbol{a}$ and $\boldsymbol{b}$ and the determination coefficient $\left(\mathrm{R}^{2}\right)$ for $\mathrm{Zn}\left({ }^{65} \mathrm{Zn}\right)$ in the soil solution at the output of the lysimeter (before the vegetation vessels) were: 263 , $-0.81(0.85)$ and $666,-0.71(0.90)$, respectively. In the soil solution after leaving the vegetation vessels and coarse filtration, they were: $262,-0.89(0.90)$ and $609,-0.76(0.90)$, respectively.

During the vegetative experiment, a significant decrease in the concentration of $\left[\mathrm{NO}_{3}{ }^{-}\right]\left(\mathrm{mg} \mathrm{dm}^{-3}\right)$ ions in the lysimetric solution was observed, while the average (at the input and output from the vegetative vessels) $\mathrm{pH}$ value increased from 5 to 7 (Figure 7a,b). The concentrations of $\left[\mathrm{K}^{+}\right]$and $\left[\mathrm{NH}_{4}{ }^{+}\right]$ions in the solution also decreased during the vegetation experiment, respectively, from $40 \pm 6$ to $11 \pm 0.5 \mathrm{mg} \mathrm{dm}^{-3}$ and from $6.0 \pm 0.9$ to $0.6 \pm 0.1 \mathrm{mg} \mathrm{dm}^{-3}$.

The values of the specific activity of ${ }^{65} \mathrm{Zn} / \mathrm{Zn}$ in studied objects are important indicators for assessing the contribution of a particular form of zinc to the soil-soil solution-plant migration chain. 

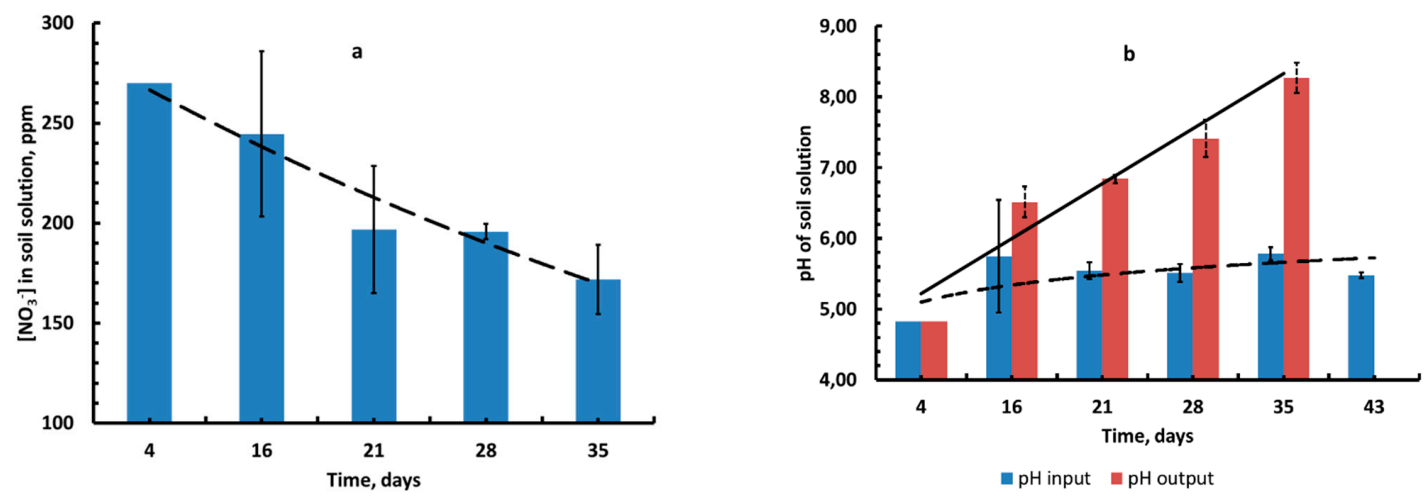

Figure 7. Concentration dynamics in soil solution (mean value \pm standard deviation; $n=3):\left[\mathrm{NO}_{3}{ }^{-}\right](\mathbf{a})$ and $\mathrm{pH}(\mathbf{b})$. Data on the 4 th day were derived from single extractions.

Data on the dynamics of the specific activity of ${ }^{65} \mathrm{Zn} / \mathrm{Zn}$ in the soil solution, vegetative parts (VPs), and roots of the test plant (barley) in terms of stable $\mathrm{Zn}$ contained in this solution (in $\mathrm{Bq} \mathrm{mg}{ }^{-1}$ ) are shown in Figure $8 \mathrm{a}-\mathrm{c}$. The average values for the vegetation period of the corresponding parameters $\mathrm{A}_{\mathrm{sp}}\left({ }^{65} \mathrm{Zn} / \mathrm{Zn}\right)_{\text {soil solution, }} \mathrm{A}_{\mathrm{sp}}\left({ }^{65} \mathrm{Zn} / \mathrm{Zn}\right)_{\mathrm{VPs}}$, $\mathrm{A}_{\mathrm{sp}}\left({ }^{65} \mathrm{Zn} / \mathrm{Zn}\right)_{\text {roots }}$ were, respectively, $3580 \pm 390,3210 \pm 1250$, and $3230 \pm 780 \mathrm{~Bq} \mathrm{mg}^{-1}$ As a result of the alkalinization of the lysimetric solution, its extracting ability with respect to the "freshly applied" ${ }^{65} \mathrm{Zn}$ gradually decreased, although not as much as with respect to the less labile native zinc. This led to pronounced trends in increasing values of $\mathrm{A}_{\mathrm{sp}}\left({ }^{65} \mathrm{Zn} / \mathrm{Zn}\right)_{\text {soil solution, }} \mathrm{A}_{\mathrm{sp}}\left({ }^{65} \mathrm{Zn} / \mathrm{Zn}\right)_{\mathrm{VPs}}$, and $\mathrm{A}_{\mathrm{sp}}\left({ }^{65} \mathrm{Zn} / \mathrm{Zn}\right)_{\text {roots }}$ during the growing season.

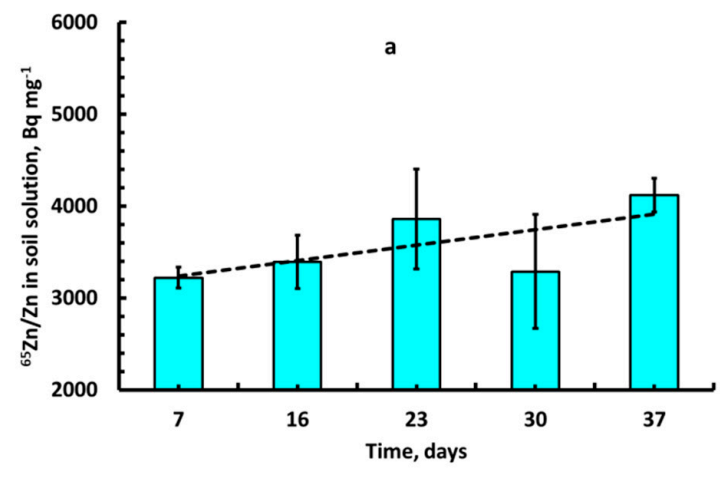

口experimental

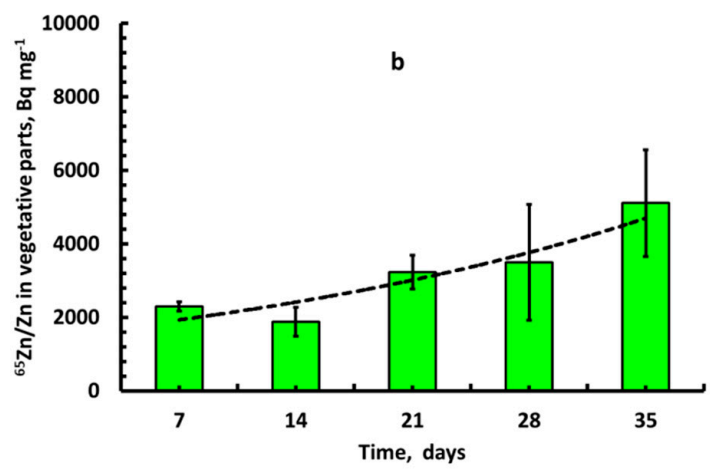

aSpecific activity $65 \mathrm{Zn} / \mathrm{Zn}$

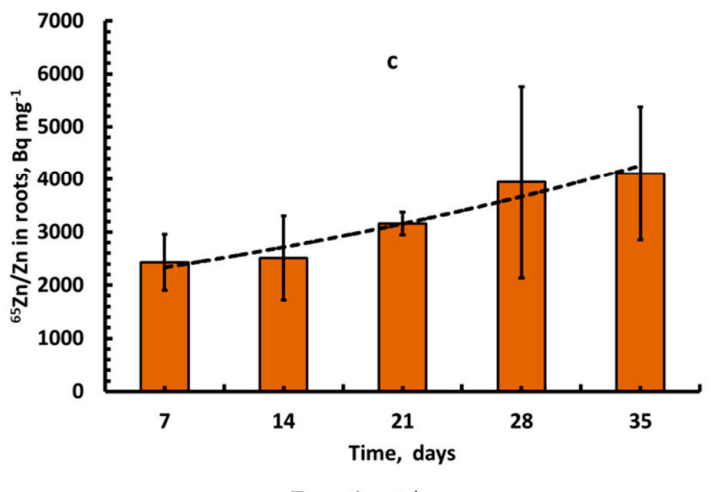

口experimental

Figure 8. Experimental data for the specific activity: $A_{s p}\left({ }^{65} \mathrm{Zn} / \mathrm{Zn}\right)_{\text {soil solution }}(\mathbf{a}), \mathrm{A}_{\mathrm{sp}}\left({ }^{65} \mathrm{Zn} / \mathrm{Zn}\right) \mathrm{VPs}$ (b), and $\mathrm{A}_{\mathrm{sp}}\left({ }^{65} \mathrm{Zn} / \mathrm{Zn}\right.$ ) roots $(\mathrm{c}), \mathrm{Bq} \times \mathrm{mg}^{-1}$ (mean value \pm standard deviation; $n=3$ ). 
The data obtained on the dynamics of the content of $\mathrm{Zn}\left({ }^{65} \mathrm{Zn}\right)$ in the vegetative parts of barley (data for roots are not given) showed that the content of zinc in the plants generally increased during ontogenesis (Figure 9a,b).
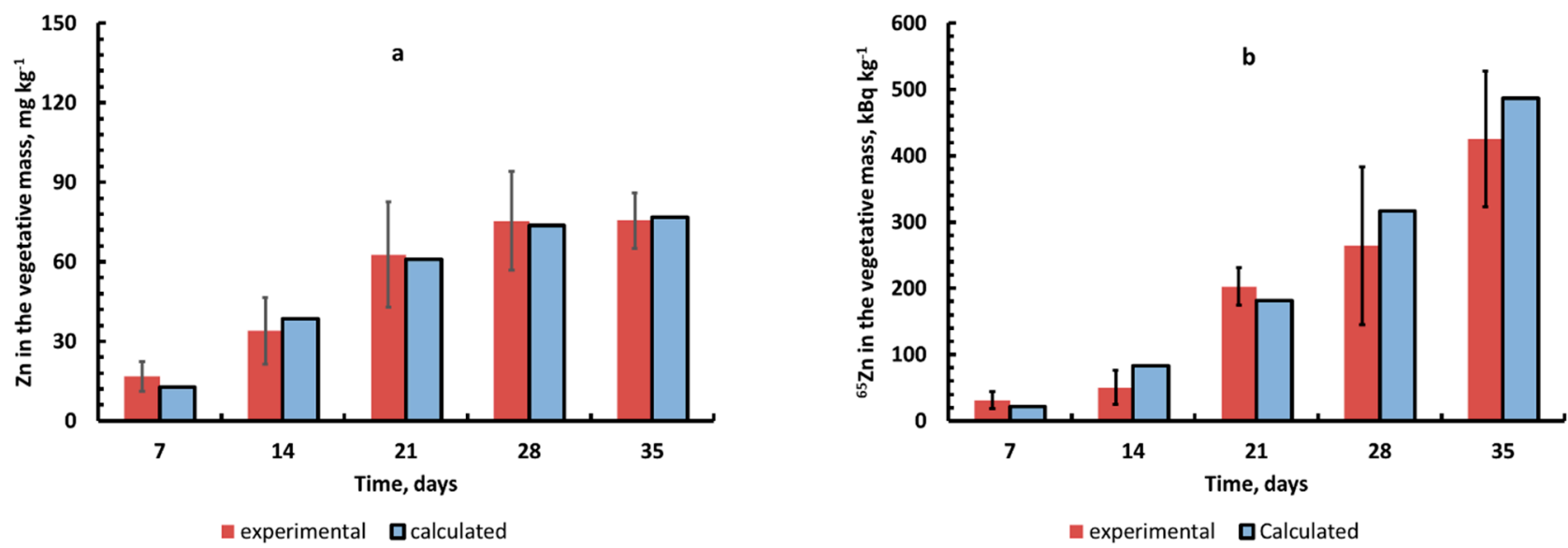

Figure 9. Dynamics of $\mathrm{Zn}$ concentration in $\mathrm{mg} \mathrm{kg}^{-1}$ (a); mass activity concentration of ${ }^{65} \mathrm{Zn}(\mathbf{b})$ (mean values \pm standard deviation; $n=3)$.

The values of the $\mathrm{Zn}\left({ }^{65} \mathrm{Zn}\right)$ concentration factors grew with increasing plant age (Figure 10) due to both the accumulative effect when zinc is absorbed by plants and decreases in its content in the soil solution during the experiment. Due to the high variability of the data, it was not possible to identify a significant difference in the values of $C F_{\mathrm{Zn}}$ and $C F_{\mathrm{Zn}-65}$.

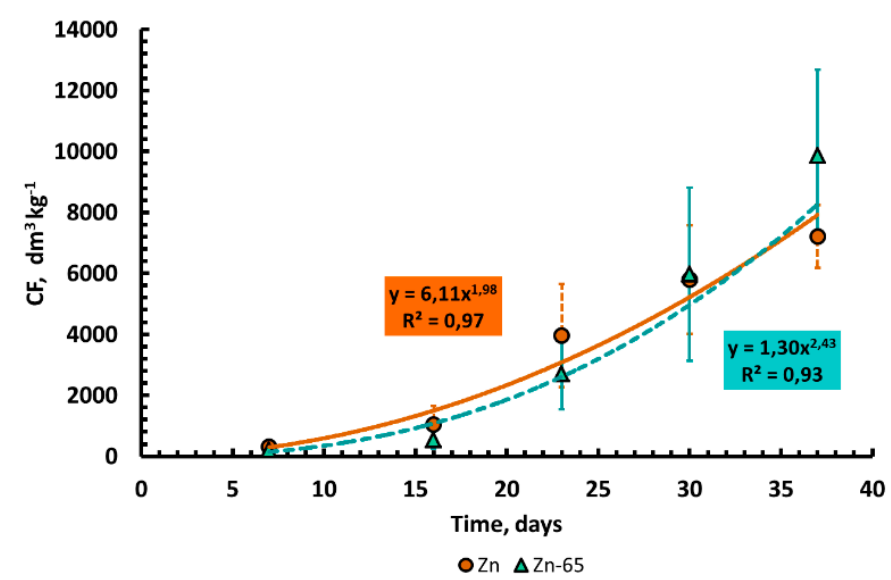

Figure 10. Dynamics of $\mathrm{Zn}\left({ }^{65} \mathrm{Zn}\right)$ concentration factors: $C F_{\mathrm{Zn}}$, and $C F_{\mathrm{Zn}-65}, \mathrm{dm}^{3} \times \mathrm{kg}^{-1}$ in the dry vegetative mass of barley (mean values \pm standard deviation; $n=3$ ).

In order to study the contribution of different soil forms to $\mathrm{Zn}$ content of the liquid phase of the soil in more detail, we used ${ }^{65} \mathrm{Zn}$ as a radioactive tracer when applying a sequential fractionation scheme of selected soil samples in accordance with the modified BCR method. The obtained results are presented in Figure 11a-c. A comparative analysis of the data showed the following ratios of different forms of stable $\mathrm{Zn}$ and radionuclide ${ }^{65} \mathrm{Zn}$ (data shown in parentheses) in soil in percent: I. $34.2 \pm 3.4$ (10.7 \pm 0.4$)$; II. $31.9 \pm 3.7$ (17.3 \pm 0.1 ; III. $9.9 \pm 2.6$ (27.8 \pm 2.3$)$; and IV. $24.0 \pm 7.7$ (42.6 \pm 3.9$)$. According to Figure $11 \mathrm{a}, \mathrm{b}$, the relative contents of labile and conditionally labile forms of ${ }^{65} \mathrm{Zn}$ in the soil (Fractions I and II) significantly exceeded the content of the corresponding forms of the stable (natural) isotope $\mathrm{Zn}$, respectively, by 3.2 and 1.8 times. 


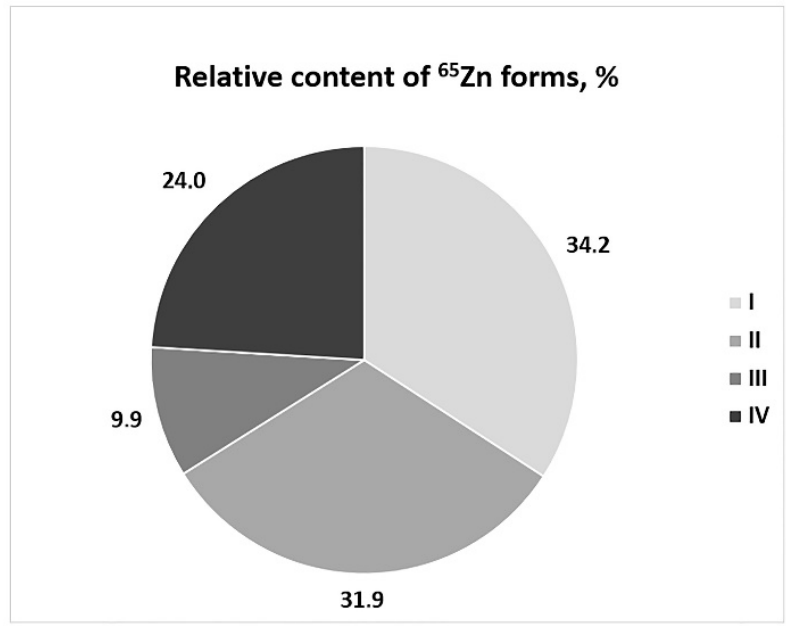

(a)

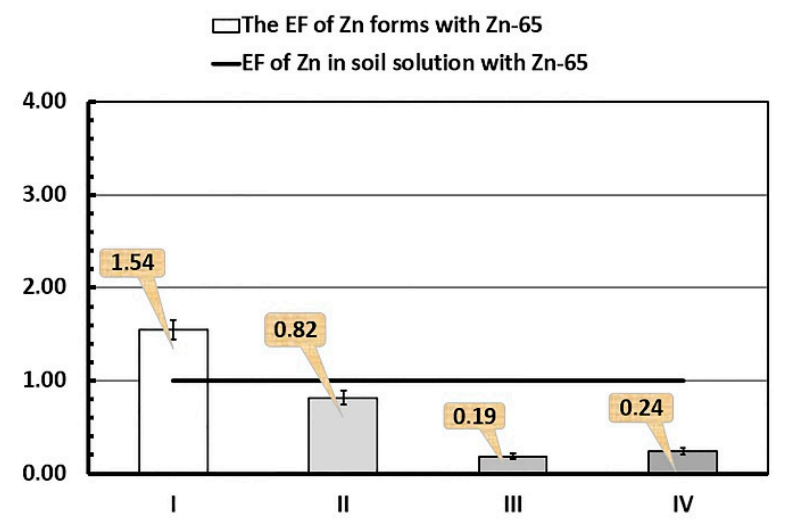

(c)
Relative content of stable $\mathrm{Zn}$ forms, \%

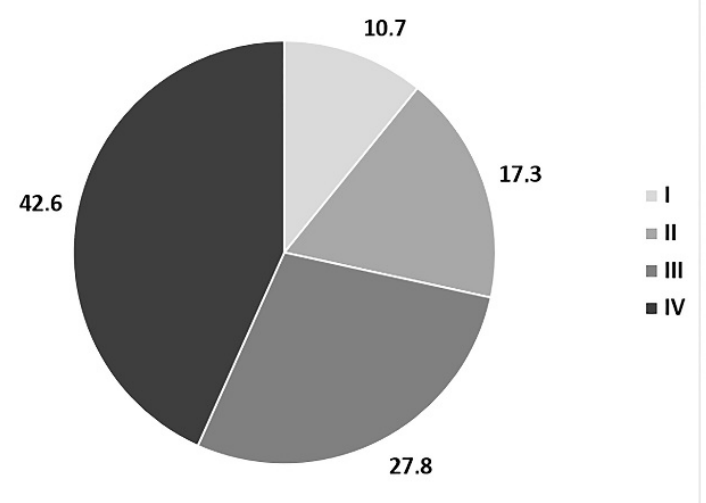

(b)

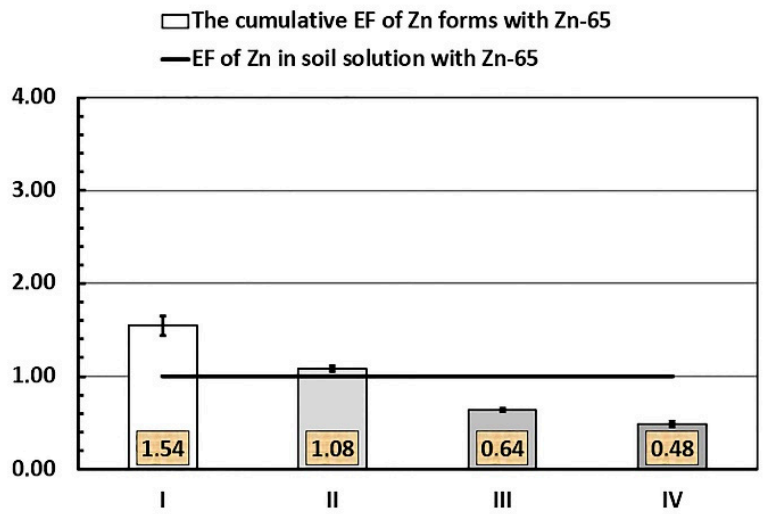

(d)

Figure 11. The relative content (\%) of the forms of stable (natural) $\mathrm{Zn}$ (a) and ${ }^{65} \mathrm{Zn}$ (b) in Albic Retisol (Loamic, Ochric) soil, as determined by the modified BCR method [21]; the enrichment factors (EF) of Zn forms by ${ }^{65} \mathrm{Zn}$ in the soil (c); the cumulative EF of $\mathrm{Zn}$ forms by ${ }^{65} \mathrm{Zn}$ in the soil (d). Roman numerals I-IV indicate the forms of zinc in the soil, as given in Table 2.

At the same time, the values of the relative content of conditionally fixed and fixed forms of ${ }^{65} \mathrm{Zn}$ in the soil (fractions III-IV) were significantly lower than that of $\mathrm{Zn}$ by 2.8 and 3.0 times, respectively.

The Enrichment Factor values of the corresponding forms of natural $\mathrm{Zn}$ with the radioactive tracer ${ }^{65} \mathrm{Zn}$ in relation to the main component of our model system-the lysimetric soil solution at the time corresponding to the beginning of the growing experimentwere: $1.54 \pm 0.11,0.82 \pm 0.07,0.19 \pm 0.03$, and $0.24 \pm 0.03$ (Figure 11c). The value of $A_{\mathrm{sp}}\left({ }^{65} \mathrm{Zn} / \mathrm{Zn}\right)_{\text {soil solution }}$ was equal to $3220 \pm 110 \mathrm{~Bq} \mathrm{mg}^{-1}$. The ordinate 1.0 secant value was an $E F\left({ }^{65} \mathrm{Zn} / \mathrm{Zn}\right)_{\text {soil solution. }}$

The cumulative form of EF data obtained are represented as a curve (Figure 11d) on which each subsequent $E F$ value is an integral value, where the ratio of the total specific activity of ${ }^{65} \mathrm{Zn}$ of this and previous fractions $\left(\mathrm{Bq} \mathrm{kg}^{-1}\right)$ to the total mass fraction of the corresponding fractions of stable $\mathrm{Zn}\left(\mathrm{mg} \mathrm{kg}^{-1}\right.$ of a soil) is normalized to the specific activity of ${ }^{65} \mathrm{Zn} / \mathrm{Zn}$ in soil solution: $E F_{\Sigma F r . \#}\left({ }^{65} \mathrm{Zn} / \mathrm{Zn}\right)=\mathrm{A}_{\mathrm{sp}}\left({ }^{65} \mathrm{Zn} / \mathrm{Zn}\right)_{\Sigma \mathrm{Fr} . \#} / \mathrm{A}_{\mathrm{sp}}\left({ }^{65} \mathrm{Zn} / \mathrm{Zn}\right)_{\text {soil solution }}$. The values of EF for the sum of the relevant forms of natural $\mathrm{Zn}$ with tracer ${ }^{65} \mathrm{Zn}$ in relation to the soil solution were $1.54 \pm 0.11$ (Fraction I), $1.08 \pm 0.03$ ( $\Sigma$ of Fractions I-II), $0.64 \pm 0.02$ ( $\Sigma$ of Fractions I-III), and $0.48 \pm 0.03$ ( $\Sigma$ of Fractions I-IV). The secant value of the coordinate 1.00 was the $E F\left({ }^{65} \mathrm{Zn} / \mathrm{Zn}\right)_{\text {soil solution. }}$. 


\subsection{Mobility of Native (Natural) Zn and Technogenic Zn in the Soil Solution-Plant System (According to Lysimetric Experience)}

For stable $\mathrm{Zn}$ and radionuclide ${ }^{65} \mathrm{Zn}$, it was found that their concentration and volumetric activity density in the soil solution decreased over time (Figure $6 a, b)$, and at the input of vegetative vessels, the corresponding concentrations were higher than at the output from the vegetative vessels, which can be explained by the uptake of zinc by barley roots. The decrease in the concentration of stable $\mathrm{Zn}$ and the volumetric activity density of radionuclide ${ }^{65} \mathrm{Zn}$ in soil solutions over time were associated with both the depletion of the pool of water-soluble forms of metals in the soil as a result of continuous uptake by plant roots (not compensated for by desorption of $\mathrm{Zn}\left({ }^{65} \mathrm{Zn}\right)$ from the cation exchange complex (CEC) into the soil solution) and the alkalinization of the soil solution by root secretions.

The decrease in the concentration of nitrate, as well as ammonium and potassium ions, in the soil solution (Figure 7a) can be described by exponential equations. It should be noted that the high concentration of nitrates led to an increase in the alkalinity of the quasi-equilibrium soil solution during the growing season (Figure $7 \mathrm{~b}$ ) due to the ability of barley to alkalize nutrient solutions in the light, releasing $\mathrm{HCO}_{3}{ }^{-}$or $\mathrm{OH}^{-}$ions in the presence of a sufficient amount of nitrate ions and a low content of ammonium ions. This fact has been reported by many researchers $[7,40,54]$. It is caused by compliance with the principle of electroneutrality during the transmembrane transfer of anions and cations to the root symplast.

It was found that the content of $\mathrm{Zn}\left({ }^{65} \mathrm{Zn}\right)$ in plants increased during ontogenesis (Figure $9 a, b$ ). This fact indicates that zinc is continuously accumulated in plants during the growth and development phases (before maturation) during ontogenesis, and this should be considered when comparing data on the metal contents in the vegetative mass of plants selected at different stages of development. We attribute a very significant increase in the values of $C F_{\mathrm{Zn}}$ and $C F_{\mathrm{Zn}-65}$ during ontogenesis to both the accumulative effect of zinc plants uptake and a decrease in its content in the soil solution during the experiment (Figure 10).

\subsection{Assessment of the Mobility of Natural Zn in the Soil-Soil Solution-Plant System Using the Radioisotope ${ }^{65} \mathrm{Zn}$ as a Tracer}

We assumed that the isotope ${ }^{65} \mathrm{Zn}$ introduced into the soil as a radioactive label was not evenly distributed between the various forms of natural (stable) $\mathrm{Zn}$, but it turned out to be primarily bound in the form of labile forms. In the future, its transformation into less labile forms should theoretically take place. This process is very long, so much so that it will not be possible to trace it for ${ }^{65} \mathrm{Zn}$ (during this time, the radionuclide will repeatedly decay). Nevertheless, it is possible to consider some theoretical aspects of the problem related to the direction and speed of transformation of ${ }^{65} \mathrm{Zn}$ forms in the soil.

It is known that in the case of the isotopic exchange of ${ }^{65} \mathrm{Zn} / \mathrm{Zn}$, we are dealing with an "ideal isotopic exchange" in which isotopic atoms that are identical in their physicochemical properties participate. In our case:

$$
\mathrm{Zn} \text { (soil form) }+{ }^{65} \mathrm{Zn}^{2+} \text { (soil solution) } \leftrightarrow{ }^{65} \mathrm{Zn} \text { (soil form) }+\mathrm{Zn}^{2+} \text { (soil solution) }
$$

The processes of ideal isotope exchange are characterized by the absence of elemental (chemical) changes, as well as the immutability of the number of interacting particles and their concentrations. The reason for the spontaneous flow of ideal isotope exchange processes is only an increase in the entropy of the system, since the change in its enthalpy in this case will be zero $(\Delta H=0)$. From a physical point of view, the increase in the entropy of the system during isotope exchange corresponds to the transition of the system from a more ordered state (different amounts of the isotope ${ }^{65} \mathrm{Zn}$ are present in different forms) to a less ordered one (the isotope is evenly distributed between the forms involved in the isotope exchange process), which corresponds to the mixing of isotopes. When an equilibrium state occurs with an ideal isotope exchange, $\Delta G^{0}=0$. Accordingly, the equilibrium constant 
$\left(K_{p}\right)=1$ [29]. For the above equation of the ideal isotope exchange ${ }^{65} \mathrm{Zn} / \mathrm{Zn}$, this ratio looks like:

$$
K_{p}=\left(\left[{ }^{65} \mathrm{Zn}\right]_{\text {soil }} \times[\mathrm{Zn}]_{\text {soil solution }}\right) /\left([\mathrm{Zn}]_{\text {soil }} \times\left[{ }^{65} \mathrm{Zn}\right]_{\text {soil solution }}\right)=1
$$

This leads to the identity of the isotopic composition of the exchanging forms:

$$
\left(\left[{ }^{65} \mathrm{Zn}\right] /[\mathrm{Zn}]\right)_{\text {soil }}=\left(\left[{ }^{65} \mathrm{Zn}\right] /[\mathrm{Zn}]\right)_{\text {soil solution }}
$$

In the case of a non-equilibrium state (as in our case), we present the following inequality:

$$
\left(\left[{ }^{65} \mathrm{Zn}\right] /[\mathrm{Zn}]\right)_{\text {soil }} \neq\left(\left[{ }^{65} \mathrm{Zn}\right] /[\mathrm{Zn}]\right)_{\text {soil solution }}
$$

The value of $\left(\left[{ }^{65} \mathrm{Zn}\right] /[\mathrm{Zn}]\right)_{\text {soil }} /\left(\left[{ }^{65} \mathrm{Zn}\right] /[\mathrm{Zn}]\right)_{\text {soil solution }}$ is the same as $E F\left({ }^{65} \mathrm{Zn} / \mathrm{Zn}\right)_{\text {soil }}$. The higher the value of EF $\left({ }^{65} \mathrm{Zn} / \mathrm{Zn}\right)_{\text {soil }}$, the further away the soil is from the state of isotopic equilibrium between radioactive and naturally stable zinc isotopes present in the solid phase in all forms (labile, conditionally labile, and fixed) on the one hand and the water-soluble form on the other hand. Due to the insignificance of the values of $\left[{ }^{65} \mathrm{Zn}\right]_{\text {soil }}$ and $\left[{ }^{65} \mathrm{Zn}\right]$ soil solution, they are usually expressed by the values of mass and volumetric activity density, respectively, of the radionuclide: $A_{m}\left({ }^{65} \mathrm{Zn}\right)_{\text {soil }}, A_{v}\left({ }^{65} \mathrm{Zn}\right)_{\text {soil solution }}$.

The solution is the most important effective phase of soil [52] at the boundary of which with solid phases ion exchange processes occur (transformation function) and a certain quasi-equilibrium state is established, as described, for example, by Equation (15). However, due to its special properties, such as its high mobility (fluidity) and high rate of diffusion transfer of dissolved substances, it acts as a connecting link due to which ion-exchange reactions (for example, the zinc isotopes considered in this paper) indirectly occur between various forms localized in different parts of the solid phase of the soil (transport function). As a result, the total net process look such that the ${ }^{65} \mathrm{Zn}$ present in some forms in the solid phase will be predominantly desorbed into the soil solution, passing into other forms.

If $\mathrm{A}_{\mathrm{sp}}\left({ }^{65} \mathrm{Zn} / \mathrm{Zn}\right)_{\mathrm{Fr} . \#}>\mathrm{A}_{\mathrm{sp}}\left({ }^{65} \mathrm{Zn} / \mathrm{Zn}\right)_{\text {soil solution, }}$ i.e., the enrichment factor of any form of $\mathrm{Zn}$ in the soil with radionuclide ${ }^{65} \mathrm{Zn}$ relative to the soil solution is greater than 1 , then the process of isotopic exchange of radionuclide between the corresponding form and the solution is shifted towards the latter. The place of ${ }^{65} \mathrm{Zn}^{2+}$ ions in the soil is occupied by ions of the natural stable isotopic carrier $\mathrm{Zn}^{2+}$ from soil solution. If $\mathrm{A}_{\mathrm{sp}}\left({ }^{65} \mathrm{Zn} / \mathrm{Zn}\right)_{\mathrm{Fr} \text {.\# }}$

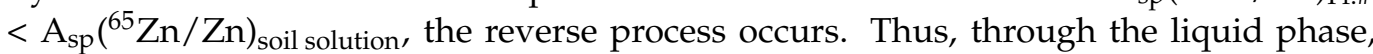
as already noted, there is an exchange of $\mathrm{Zn}\left({ }^{65} \mathrm{Zn}\right)$ between competing binding sites in the solid phase of soils, forming with zinc ions the corresponding chemical forms. The concentration of [ $\mathrm{Zn}]$ and the volumetric activity density of ${ }^{65} \mathrm{Zn}$ in a quasi-equilibrium soil (lysimetric) solution reflect the contribution of it different forms in the studied soil.

Values of the enrichment factor of the labile chemical $\mathrm{Zn}$ fraction (Fraction I) via the radioactive tracer ${ }^{65} \mathrm{Zn}\left(E F\left({ }^{65} \mathrm{Zn} / \mathrm{Zn}\right)_{\text {Fr.I }}=1.54>1\right.$, while $E F\left({ }^{65} \mathrm{Zn} / \mathrm{Zn}\right)_{\text {Fr.II }}=0.82, E F$ $\left({ }^{65} \mathrm{Zn} / \mathrm{Zn}\right)_{\text {Fr.III }}=0.19$, and $E F\left({ }^{65} \mathrm{Zn} / \mathrm{Zn}\right)_{\text {Fr.IV }}=0.24$ were less then 1 (Figure $\left.11 \mathrm{c}\right)$. This allowed us to assume that in the soil-soil solution system from chemical Fraction I, ${ }^{65} \mathrm{Zn}^{2+}$ ions were predominantly desorbed into the soil solution, and for fractions II-IV, in contrast, were sorbed from the solution, which gradually led to a decrease in $\mathrm{A}_{\mathrm{sp}}\left({ }^{65} \mathrm{Zn} / \mathrm{Zn}\right)$ for the first fraction and an increase for the second group of fractions.

Based on the obtained results and the assumption of the increasing ability of extractants used in the sequential extraction of zinc ions [20], it was possible to calculate the pool of labile zinc in the unit of soil mass-the " $E$-value": $\left(E_{\mathrm{Zn}}\right)=\mathrm{C}(\mathrm{Zn})_{\mathrm{Fr} . \mathrm{I}}=3.95 \pm 0.16 \mathrm{mg} \mathrm{kg}^{-1}$ (or $10.7 \pm 0.4 \%$ ). The corresponding specific activity value was ${ }^{65} \mathrm{Zn}\left(\mathrm{A}_{\mathrm{sp}}\left({ }^{65} \mathrm{Zn} / \mathrm{Zn}\right)_{\text {Fr.I }}\right)$ equal to $4660 \pm 830 \mathrm{~Bq} \times \mathrm{mg}^{-1}$.

Attention is drawn to the fact that the average value during the growing season $\mathrm{A}_{\mathrm{sp}}\left({ }^{65} \mathrm{Zn} / \mathrm{Zn}\right)_{\text {soil solution }}=3580 \pm 390 \mathrm{~Bq} \mathrm{mg}{ }^{-1}<\mathrm{A}_{\mathrm{sp}}\left({ }^{65} \mathrm{Zn} / \mathrm{Zn}\right)_{\text {Fr.I }}$. This allowed us to assume the existence of a slow process of isotopic exchange between mobile and other 
("conditionally labile", "conditionally fixed", and "fixed") forms of zinc by means of the liquid phase of the studied soil-soil solution. It was possible to fix this moment thanks to a long process of preliminary equilibration of ${ }^{65} \mathrm{Zn}$ with the studied soil.

Later, during the vegetation experiment, as a result of the vital activity of plants, the soil solution was depleted with zinc and alkalized, which led to an increase in the value of $\mathrm{A}_{\mathrm{sp}}\left({ }^{65} \mathrm{Zn} / \mathrm{Zn}\right)_{\text {soil solution }}$ to values close to $\mathrm{A}_{\mathrm{sp}}\left({ }^{65} \mathrm{Zn} / \mathrm{Zn}\right)$ Fr. (Figure $\left.9 \mathrm{a}\right)$, which actually reflected the ratio of ${ }^{65} \mathrm{Zn} / \mathrm{Zn}$ in labile and "conditionally labile" forms in the soil and their contribution to the composition of a quasi-equilibrium soil solution.

For balance calculations and the study of the transformation of the forms of $\mathrm{Zn}\left({ }^{65} \mathrm{Zn}\right)$ in the soil, data on the total removal of both natural and radioactive zinc isotopes from the soil-soil solution system by vegetative parts and barley roots are of particular interest (recall that five plant selections were made in total). We found that the percentage of the total amount of $\mathrm{Zn}\left({ }^{65} \mathrm{Zn}\right)$ contained in the soil was insignificant and amounted to only 0.34 $(0.70) \%$. Consequently, the removal of metal by plants had no noticeable effects on the ratio of the forms of zinc in the soil.

\section{Materials and Methods}

The behavior of $\mathrm{Zn}$ in a soil-plant system was studied in vegetation experiments with soil culture with increasing zinc concentration in the soil (greenhouse conditions), in vegetation experiments with water culture with increasing zinc concentration in a soil nutrient solution (greenhouse conditions), and in a lysimetric experiment with an aqueous culture with the sole application of radioactive ${ }^{65} \mathrm{Zn}$ to the soil (laboratory conditions).

Barley (Hordeum vulgare L.) of the Zazersky-85 variety and soddy-podzolic sandy loam cultivated soil-Albic Retisol (Loamic, Ochric) not containing free carbonates selected from the arable horizon of agricultural land near Obninsk (Kaluga region, Russia) were selected as our objects of research.

\subsection{Experiment with the Soil Culture of Barley}

During the research, most attention was paid to the root uptake and redistribution of $\mathrm{Zn}$ between different parts of barley plants. To do this, $5 \mathrm{~kg}$ of air-dry Albic Retisol (Loamic, Ochric) soil were placed into vessels. Nutrients were applied to the soil in the form of aqueous solutions of $\mathrm{KH}_{2} \mathrm{PO}_{4}$ and $\mathrm{K}_{2} \mathrm{SO}_{4}$ salts at rates of $100 \mathrm{mg} \mathrm{kg}^{-1} \mathrm{P}$ and $\mathrm{K}$, respectively, and $\mathrm{Zn}$ was applied in the form of nitrate solutions.

The amount of $\mathrm{Zn}$ applied to the soil was as follows: 0, 25, 50, 100, 175, 250 and $500 \mathrm{mg} \mathrm{kg}^{-1}$. The amount of nitrogen introduced with $\mathrm{Zn}\left(\mathrm{NO}_{3}\right)_{2}$ was adjusted according to the variant with the sub-maximum dose of $\mathrm{Zn}$ using $\mathrm{NH}_{4} \mathrm{NO}_{3}$ (but no more than $1 \mathrm{~g} \mathrm{~N} /$ vessel). After applying salt solutions, the soils in the vessels were incubated for 30 days at a temperature of $20-23^{\circ} \mathrm{C}$. Twenty five barley seeds were sown in each vessel. The plants on the green mass were harvested at 7, 14, 21, 30, 45 and 70 days after sowing. The experiment was carried out in triplicate.

The experiment was carried out at a temperature of $20-29{ }^{\circ} \mathrm{C}$, relative humidity of $55-75 \%$, and soil mass moisture content of $60 \%$ of the full water capacity (FWC).

Exchangeable potassium, calcium, and magnesium were extracted from soils using different reagents: $1 \mathrm{M} \mathrm{NH}_{4} \mathrm{Cl}$ ( $\mathrm{pH}$ 6.5); $1 \mathrm{M} \mathrm{CH}_{3} \mathrm{COONH}_{4}, \mathrm{pH} 7.0$ (AAB-7.0); and $1 \mathrm{M}$ $\mathrm{CH}_{3} \mathrm{COONH}_{4}, \mathrm{pH} 4.8$ (AAB-4.8) [55], respectively, before a negative reaction to $\mathrm{Ca}^{2+}$ ions. The physical and chemical parameters of the studied soil were determined with conventional methods [55,56]: $\mathrm{pH}_{\mathrm{KCl}}\left(\mathrm{pH}_{\text {water }}\right)$ was determined with a potentiometric method in a suspension of soil in $1 \mathrm{M}$ solution of $\mathrm{KCl}$ (distilled water) with a ratio of solid and liquid phases (S:L) = 1:2.5 (1:25 for peat soil), the granulometric composition of soil was determined with the pipette method of N.A. Kachinsky [48,55], humus content was determined by means of bichromatic oxidation by the Tyurin method, hydrolytic acidity was determined by means of the Kappen method, the sum of exchange bases was determined by means of the Kappen-Gilkovitz method, and the content of labile forms of 
$\mathrm{P}_{2} \mathrm{O}_{5}$ was determined by means of by the Kirsanov method in the modification of TSINAO $(0.2 \mathrm{M} \mathrm{HCl}, \mathrm{S}: \mathrm{L}=1: 5)$.

The combination of easily and difficult-to-exchange forms of $\mathrm{Zn}\left({ }^{65} \mathrm{Zn}\right)[18,34,57]$ was extracted using $1 \mathrm{M} \mathrm{CH}_{3} \mathrm{COONH}_{4}$ at $\mathrm{pH} 4.8$ with the modified method proposed by N.G. Zyrin [32] - by successive, exhaustive extractions to a negative reaction to $\mathrm{Ca}^{2+}$. The potential buffering capacity of soils with respect to $\mathrm{Zn}$ was determined by the Beckett method $[47,49,50]$ using $0.01 \mathrm{M} \mathrm{CaCl}_{2}$.

\subsection{Experiment with Water Culture of Barley}

Our experiments were carried out on constantly aerated and mixed nutrient solutions extracted from the studied soil at a narrow soil:solution ratio $=1: 2$, in which, in addition to the background concentration $(0.07 \mu \mathrm{M}), \mathrm{Zn}$ was added in the form of nitrate at the following concentrations: $0,0.63,5.8,29,57,114$ and $430 \mu \mathrm{M}$. In the soil solutions, the amount of applied $\mathrm{Zn}\left(\mathrm{NO}_{3}{ }^{-}\right)_{2}$ of $\mathrm{N}\left(\mathrm{NO}_{3}{ }^{-}\right)$was adjusted according to the variant with a $114 \mu \mathrm{M}$ dose of $\mathrm{HM}$ using $\mathrm{Ca}\left(\mathrm{NO}_{3}\right)_{2}$ ("puriss") at the rate of $0.2 \mathrm{mM} \mathrm{N}\left(\mathrm{NO}_{3}{ }^{-}\right)$. The contents of macroelement cations in nutrient solutions were (in $\mathrm{mM}$ ): $1.60 \pm 0.05 \mathrm{Ca}^{2+}$ (considering the added in the form of $\left.\mathrm{Ca}\left(\mathrm{NO}_{3}\right)_{2}\right) ; 0.16 \pm 0.02 \mathrm{Mg}^{2+}$, and $0.38 \pm 0.02 \mathrm{~K}^{+}$. The $\mathrm{pH}$ value of the nutrient solutions was adjusted to 5.8 , corresponding to the acidity of a solution containing $114 \mu \mathrm{M} \mathrm{Zn}^{2+}$, using solutions of $\mathrm{CitH}_{3}$ and $\mathrm{NaOH}$. The total content of citric acid anion in nutrient solutions was $0.05 \mathrm{mM}$. The plants were grown for 21 days, and we changed the solution to a fresh one daily.

\subsection{Lysimetric Experiment with Water Culture of Barley}

The vegetation experiment was carried out using a special stand, including a flow lysimetric installation of an original design (Figures 12 and A1 in Appendix A). In addition to the cyclic lysimetric installation, which provided the gravity runoff of soil moisture, the stand included:

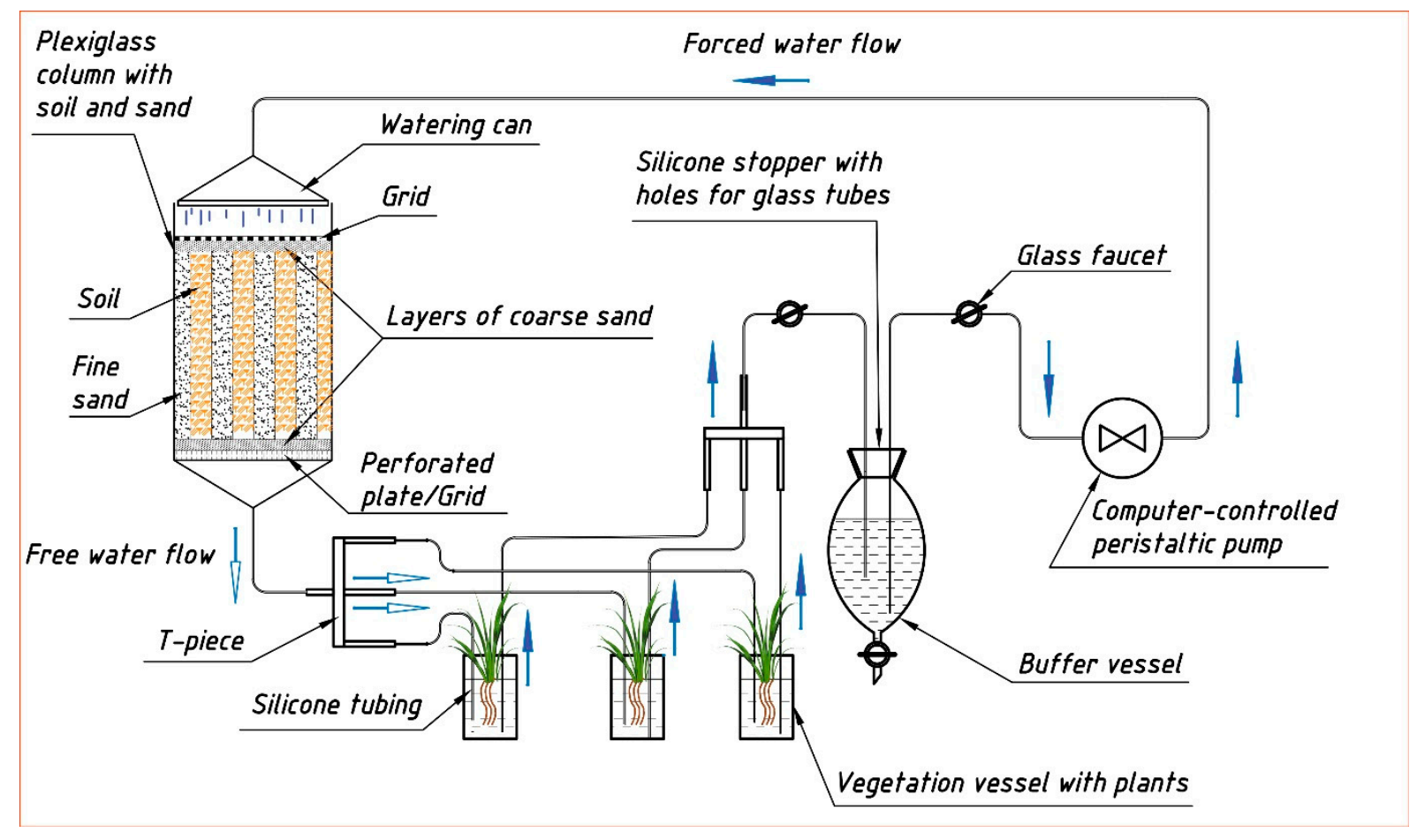

Figure 12. Structural and dynamic scheme of the stand used for studying the parameters of $\mathrm{Zn}\left({ }^{65} \mathrm{Zn}\right)$ migration in the soil-soil solution-plant system (opened blue arrow is designated to soil solution before vegetation vessels (input), filled blue arrow-after them (output)). 
- Flowing vegetative vessels with a soil solution in which sprouted plant seeds were placed on special stands in containers with a mesh bottom (nylon fabric) filled with coarse sand.

- A peristaltic pump.

- A system of tubes, taps, and adapter tees; a buffer tank.

- A lighting source for plants. From above, the flow lysimeter was non-hermetically covered with a plexiglass lid with a sprinkler device.

The preliminary preparation of the soil included the introduction of $200 \mathrm{kBq} \mathrm{kg}^{-1}$ of radionuclide ${ }^{65} \mathrm{Zn}$ ( $\mathrm{T}_{1 / 2}=224$ days) in the form of a working solution of ${ }^{65} \mathrm{Zn}$ (II) without an isotopic carrier such as stable $\mathrm{Zn}$. The working solution was prepared from a sample solution of ${ }^{65} \mathrm{Zn}$ (II) in $0.1 \mathrm{M} \mathrm{HCl}$ ("CYCLOTRON Co., Ltd.", Obninsk, Russia), which contained $42.4 \mathrm{MBq}{ }^{65} \mathrm{Zn}$ at the time of certification. The mass activity density of the soil due to the presence of the radioisotope ${ }^{65} \mathrm{Zn}\left(\mathrm{Am}^{65} \mathrm{Zn}_{\text {soil }}\right)$ at the beginning of the vegetation experiment under consideration was $68,700 \pm 2800 \mathrm{~Bq} \mathrm{~kg}{ }^{-1}$.

The resulting soil suspension after the application of the radionuclide was thoroughly mixed and incubated at room temperature for $\frac{1}{2}$ year, moistened twice a month, and dried in air (preventing complete drying). Then, the dried soil was ground and passed through a sieve with a diameter of $2 \mathrm{~mm}$. The soil prepared in this way, containing ${ }^{65} \mathrm{Zn}$, was placed in layers in a lysimetric installation with alternating layers of soil and washed quartz sand with a particle diameter of $<1 \mathrm{~mm}$ as drainage (Figure 12). To prevent the colmatation of soil pores under the gravitational current of moisture, soil/sand layers were vertically oriented.

The total amount of deposited sand and soil was $5 \mathrm{~kg}$ each. The thickness of the layers was $2.5 \mathrm{~cm}$. After that, the soil-soil solution system has been balanced in the lysimeter for 5 months by pouring deionized water onto the soil surface in the lysimeter and periodically returning the water flowing from the lysimeter back to the soil surface. Three weeks before the start of the vegetation experiment, a growing installation was assembled and water was added to the system up to a total volume of $5.5 \mathrm{dm}^{3}$ along with the nutrient solutions at the rates of $100 \mathrm{mg} \mathrm{kg}^{-1} \mathrm{~N}$ and $\mathrm{K}$ in the forms of $\mathrm{NH}_{4} \mathrm{NO}_{3}$ and $\mathrm{K}_{2} \mathrm{SO}_{4}$, respectively. Additional phosphorus was not applied, since the content of its labile forms in the soil was sufficient (Table 1). After assembly, the lysimetric installation and vegetative vessels were wrapped with a light-tight film. Then, the peristaltic pump was started and the system was left in operation for balancing for 3 weeks. Considering that the total volume of the liquid phase in the system was about 5.5. $\mathrm{dm}^{3}$ and the rate of water supply by the peristaltic pump through the sprinkler device was $4 \mathrm{~cm}^{3}$ per minute, the soil solution was subjected to complete regeneration, passing through the lysimeter, during the day.

The plants were grown in glass vegetation vessels with a volume of $2 \mathrm{dm}^{3}$ in triplicate. The volume of the soil lysimetric solution in each vessel was approximately $1.25 \mathrm{dm}^{3}$. The mixing of solutions was carried out by continuously bubbling air supplied to each vegetative vessel through thin silicone tubes using a low-power compressor. To compensate for evaporating moisture, the total volume of deionized water added daily to the soil surface in the lysimeter was 150-200 mL. In each vegetative vessel, a plastic separator was placed on stands with 6 large holes into which cartridges filled with large washed quartz sand (2-3 mm), closed from below with a nylon cloth, were inserted. Three barley seedlings sprouted within 3 days were planted in each cartridge. When barley roots appeared outside the cartridges, the latter were slightly raised above the water surface, ensuring that the roots were in the water. At the same time, the movement of water in the vegetative vessels caused by bubbling was sufficient to wet the substrate (sand) inside the cartridges. The duration of the vegetation experiment was 35 days. In total, 5 plant selections were made during the experiment each week (the 1st selection was double due to the small amount of plant material). 


\subsection{Determination of $\mathrm{Zn}\left({ }^{65} \mathrm{Zn}\right)$ Forms (Chemical Fractions) in the Soil}

Using AAB-4.8, "labile (available to plants)" forms of zinc were extracted from the soil using successive exhaustive extractions before a negative reaction to $\mathrm{Ca}^{2+}$ ions [32,35].

To determine the content of ${ }^{65} \mathrm{Zn}(\mathrm{Zn})$ associated with different organo-mineral fractions with the BCR method [21] (Table 3), the soil samples were preliminarily prepared.

Table 3. Sequental Extraction Procedure by BCR modified method [21].

\section{\#Form (Chemical Fraction of} $\mathrm{Zn}\left({ }^{65} \mathrm{Zn}\right) /$ Extraction with

\section{Procedure}

I. A sample of raw soil of known humidity (corresponding to $1 \mathrm{~g}$ of absolutely dry soil) without signs of gluing was placed in a $50 \mathrm{~mL}$ centrifuge tube. Then, $40 \mathrm{~cm}^{3}$ of Solution A were added, the tube was closed with a lid, and the material was extracted by shaking for $16 \mathrm{~h}$ at $22.5^{\circ} \mathrm{C}$ (or overnight) on a rotator. There was no delay between the addition of the extractant solution and the start of shaking.

I. Exchangeable and carbonate bound/Acetic acid, Then, the extract was separated from the solid precipitate by centrifugation at $3000 \mathrm{~g}$ for $20 \mathrm{~min}$ $0.11 \mathrm{M}$ and the subsequent decantation of the supernatant into a volumetric glass flask $(\mathrm{V}=100 \mathrm{~mL})$ with a polished stopper. Next, $20 \mathrm{~cm}^{3}$ of deionized water were added to the sediment, which was shaken for $15 \mathrm{~min}$ on a reciprocating shaker and centrifuged for $20 \mathrm{~min}$ at $3000 \mathrm{~g}$, and the washing waters were separated by decantation and combined with the extract in a measuring flask. The solution in the flask was brought to the mark with deionized water, stirred, filtered through a 0.45 microns membrane filter, and analyzed for the content of $\mathrm{Zn}\left({ }^{65} \mathrm{Zn}\right)$.

II. We added $40 \mathrm{~cm}^{3}$ of freshly prepared Solution B to the remaining soil after stage (I) in a centrifuge tube (see above). The contents were mixed, achieving the complete dispersion of the residue by manual shaking. The centrifuge tube was closed with a lid, and the studied elements were extracted from the soil by mechanical shaking for $16 \mathrm{~h}$ at $22.5^{\circ} \mathrm{C}$ (night). There was no

II. Associated with reducible Fe-Mn oxides/Hydroxylammonium Chloride (Hydroxylamine Hydrochloride), $0.5 \mathrm{M}(\mathrm{pH}$ $1.5, \mathrm{HNO}_{3}, 2 \mathrm{M}$ fixed vol.) delay between the addition of the extractant solution and the start of shaking. The procedure for separating the extract, washing the sediment, and preparing the analyte sample was performed in the same way as in step (I). It was necessary to carefully ensure that during the last operation we did not accidentally lose part of the solid residue.

III. We carefully added $10 \mathrm{~cm}^{3}$ of Solution C (in small aliquots to avoid losses due to a violent reaction) to the remainder of the soil in a centrifuge tube after stage (II). Then, we covered the tube with a lid (loosely) and kept it for $1 \mathrm{~h}$ at room temperature (shaking by hand periodically) to oxidize the organic components of the soil with hydrogen peroxide. Then, the oxidation was continued for another $1 \mathrm{~h}$ at $85 \pm 2{ }^{\circ} \mathrm{C}$ in a water bath; during the first $\frac{1}{2}$ hour, centrifuge tubes with soil and extraction solution were periodically manually shaken.

The volume of the contents in the test tube with the lid removed was evaporated to approximately $\mathrm{V}<3 \mathrm{~cm}^{3}$. Then, aliquots of Solution $\mathrm{C}$ with a volume of $10 \mathrm{~cm}^{3}$ were repeatedly added to the contents of the centrifuge tube. We covered the tube with a lid (leaky) and again continued the oxidation of its contents for another $1 \mathrm{~h}$ at $85 \pm 2{ }^{\circ} \mathrm{C}$, periodically manually shaking the centrifuge tubes for the first $\frac{1}{2}$ hour. Then, we removed the lid and evaporated the liquid in the test tube to about $\mathrm{V} \approx 1 \mathrm{~cm}^{3}$, thus preventing the complete drying of the sample. We added $50 \mathrm{~mL}$ of Solution $\mathrm{D}$ to the cooled wet residue in the test tube and shook it for $16 \mathrm{~h}$ at a temperature of $22 \pm 5{ }^{\circ} \mathrm{C}$ (or overnight). There was delay between the addition of the extractant solution and the start of shaking. The procedure for separating the extract, washing the sediment, and preparing the analysis sample was performed in the same way as in step (I).

Solution A. In a fume cupboard, we added $25 \pm 0.2 \mathrm{~cm}^{3}$ of glacial acetic acid to about $0.5 \mathrm{dm}^{3}$ of distilled water in a $1 \mathrm{dm}^{3}$ graduated polypropylene or polyethylene bottle and made up to $1 \mathrm{dm}^{3}$ with distilled water. We took $250 \mathrm{~cm}^{3}$ of this solution (acetic acid, $0.43 \mathrm{M}$ ) and diluted it to $1 \mathrm{dm}^{3}$ with distilled water to obtain an acetic acid solution of $0.11 \mathrm{M}$.

Solution B. We dissolved $34.75 \mathrm{~g}$ of hydroxylammonium chloride in $400 \mathrm{~cm}^{3}$ of distilled water. We transferred the solution to a $1 \mathrm{~L}$ volumetric flask, and added $25 \mathrm{~cm}^{3}$ of $2 \mathrm{M} \mathrm{HNO}_{3}$ (prepared by weighing from a suitable concentrated solution) by means of a volumetric pipette. We made up to 1 $\mathrm{dm}^{3}$ with distilled water. We prepared this solution on the same day the extraction was carried out.

Solution C. $8.8 \mathrm{M}$ water solution $\mathrm{H}_{2} \mathrm{O}_{2}$ (comprised $300 \mathrm{mg} \mathrm{g}^{-1}$ of hydrogen peroxide), was stabilized with $\mathrm{HNO}_{3}$ to $\mathrm{pH} 2-3$. It is recommended to use hydrogen peroxide acid-stabilized by the manufacturer to $\mathrm{pH} 2-3$.

Solution $D$. We dissolved $77.08 \mathrm{~g}$ of ammonium acetate in $800 \mathrm{~mL}$ of distilled water and adjust the $\mathrm{pH}$ to $2.0 \pm 0.1$ with concentrated $\mathrm{HNO}_{3}$ and made up to $1 \mathrm{~L}$ with distilled water.

Various forms of ${ }^{65} \mathrm{Zn}(\mathrm{Zn})$ were determined in the soil located in the lysimeter at moisture content (W = FMC (field moisture capacity)) just before the vegetation experiment. A mixed soil sample was obtained by combining micro-samples $(\mathrm{m} \approx 5 \mathrm{~g}$ ) extracted with the use of a special bore made of a chemically inert material (a total of 10 injections). After the careful homogenization of the combined sample, subsamples of raw soil material with known humidity underwent successive chemical extraction in accordance with the BCR fractionation scheme. 
In order to facilitate the further analysis and discussion of the obtained data, we introduced the special classification of the forms of $\mathrm{Zn}\left({ }^{65} \mathrm{Zn}\right)$ in the soil: exchange and carbonate bonds denoted as "labile"; bonds associated with recoverable Fe-Mn oxides denoted as "conditionally labile"; bonds associated with oxidizable organic matter and sulfides denoted as "conditionally fixed"; and residue denoted as "fixed".

\subsection{Elemental Analysis and $\gamma$-Spectrometry of Samples}

During the vegetation experiments, the following dynamics were determined:

- Concentrations of zinc and the mass activity density of ${ }^{65} \mathrm{Zn}$ in soil (including different forms) and plants: $[\mathrm{Zn}]_{\text {soil }}$ and $[\mathrm{Zn}]_{\text {plant }}\left(\mathrm{mg} \mathrm{kg}^{-1}\right) ; \mathrm{A}_{\mathrm{m}}\left({ }^{65} \mathrm{Zn}\right)_{\text {soil }}$ and $\mathrm{A}_{\mathrm{m}}\left({ }^{65} \mathrm{Zn}\right)_{\text {plant }}$, $\left(\mathrm{Bq} \mathrm{kg}^{-1}\right)$.

- Concentration of $\mathrm{Zn}$ and the volumetric activity density of ${ }^{65} \mathrm{Zn}$ in the phase of the soil solution: $[\mathrm{Zn}]_{\text {soil solution }}\left(\mu \mathrm{g} \mathrm{L}^{-1}\right)$ and $\mathrm{A}_{\mathrm{V}}\left({ }^{65} \mathrm{Zn}\right)$ soil solution $\left(\mathrm{Bq} \mathrm{L}{ }^{-1}\right)$, respectively.

Values of mass and volumetric activity density of ${ }^{65} \mathrm{Zn}$ were calculated on the date of the beginning of the vegetation experiment.

Based on the above parameters, the values of the key parameter, conventionally called the "specific activity of ${ }^{65} \mathrm{Zn} / \mathrm{Zn}$ ", were calculated in lysimetric waters, individual chemical fractions (forms) of zinc in the soil, and parts of plants. These were determined as the ratio of mass or volumetric activity density to the concentration of stable $\mathrm{Zn}$ contained in the corresponding objects of study $\left(\mathrm{Bq} \mathrm{mg}^{-1}\right)$ :

\begin{tabular}{cc}
\hline $\begin{array}{c}\text { - In solution } \\
\text { - In the soil as a whole, and in individual chemical } \\
\text { fractions of the soil }\end{array}$ & $\mathrm{A}_{\mathrm{sp}}\left({ }^{65} \mathrm{Zn} / \mathrm{Zn}\right)_{\text {solution }}=\mathrm{A}_{\mathrm{v}}\left({ }^{65} \mathrm{Zn}\right) /[\mathrm{Zn}]_{\text {solution }}$ \\
- In vegetative parts (VPs) of plants & $\mathrm{A}_{\mathrm{sp}}\left({ }^{65} \mathrm{Zn} / \mathrm{Zn}\right)_{\text {Fr.\# }}=\mathrm{A}_{\mathrm{m}}\left({ }^{65} \mathrm{Zn}\right)_{\mathrm{Fr} . \#} /[\mathrm{Zn}]_{\mathrm{Fr} . \#}$ \\
- In roots & $\mathrm{A}_{\mathrm{sp}}\left({ }^{65} \mathrm{Zn} / \mathrm{Zn}\right)_{\mathrm{VP}}=\mathrm{A}_{\mathrm{m}}\left({ }^{65} \mathrm{Zn}\right)_{\mathrm{VP}} /[\mathrm{Zn}]_{\mathrm{VP}}$ \\
\hline
\end{tabular}

Using the specific activity of ${ }^{65} \mathrm{Zn} / \mathrm{Zn}$, the values of the parameter we called "Enrichment Factors-EF $\left({ }^{65} \mathrm{Zn} / \mathrm{Zn}\right.$ ) (or simply $E F$ )—were calculated. These factors comprised the enrichment with the radioactive tracer ${ }^{65} \mathrm{Zn}$ of natural (stable) $\mathrm{Zn}$ contained in soil (including individual chemical fractions) and plants in relation to the main component of our model system-soil solution, e.g., $E F_{\text {Fr.\# }}\left({ }^{65} \mathrm{Zn} / \mathrm{Zn}\right)=\mathrm{A}_{\mathrm{sp}}\left({ }^{65} \mathrm{Zn} / \mathrm{Zn}\right)$ Fr.\# $/ \mathrm{A}_{\mathrm{sp}}\left({ }^{65} \mathrm{Zn} / \mathrm{Zn}\right)_{\text {soil solution }}$.

The concentrations of $\mathrm{Zn}\left({ }^{65} \mathrm{Zn}\right)$ in the roots and vegetative parts (VP) of barley plants were determined after the dry ashing of samples at $500{ }^{\circ} \mathrm{C}$ followed by the acid extraction of metal $\mathrm{HNO}_{3}$; the total (gross) mass fraction of elements in the soil was determined by the Obukhov-Plekhanova method [58] after ashing at $500{ }^{\circ} \mathrm{C}$ and the subsequent decomposition of samples using heating with an $\mathrm{HCl}_{\text {conc. }}+\mathrm{HNO}_{3 \text { conc. }}+\mathrm{HF}_{\text {conc. mixture }}$ followed by successive treatments by $\mathrm{HF}_{\text {conc }}$ (twice) and $\mathrm{HNO}_{3 \text { conc }}$ (triplicate).

Elemental analysis was carried out via the atomic absorption and optical emission methods with inductively coupled plasma using 140AA (Agilent) and Liberty II (Varian) spectrometers. The mass and volumetric activity densities of ${ }^{65} \mathrm{Zn}$ were determined on a gamma-spectrometric complex consisting of an ORTEC HPGe detector and analyzer (with a relative recording efficiency of $40 \%$ ) and LSRM SpectraLine GP software.

\subsection{Statistical Analysis}

The accuracy of the approximating equations used to describe the obtained dependencies was estimated using the $t$-criterion and the coefficients of determination $\mathrm{R}^{2}$. The statistical analysis of experimental data was carried out by standard methods using MSExcel based on the theoretical aspects set out in the works [59-61].

\section{Conclusions}

For the studied soils, various types of plant responses to changes in the concentration of $\mathrm{Zn}$ were determined using barley as the test plant. Ranges of corresponding concentrations in soils and various parts of test plants were established.

It was shown that the edaphic factors determining the buffering capacity of soils play no less important roles in regulating the mobility of $\mathrm{Zn}$ in the soil-plant system than the 
biological factor (physiological characteristics of plants). For Zn, the concentration ratios $(C R s)$ and concentration factors $(C F s)$ in various parts of plants were found to be constant in the area of the indicative type of plant response to changes in the metal contents in soils (for example, we found values of $C R_{\text {labile }}=5.68$ and $C F=640 \mathrm{~L} \mathrm{~kg}^{-1}$ for the vegetative mass of barley).

A method was proposed for determining the buffer capacity of soils with respect to HMs $\left(P B C(V)_{\mathrm{HM}}\right)$ using barley as the test plant (the tested part of the plant was leaves). With this method, we determined the value of $P B C(V)_{\mathrm{Zn}}$ in the field of non-toxic zinc concentrations for the studied Albic Retisol (Loamic, Ochric)soil to be $175 \mathrm{mmol} \mathrm{kg}^{-1}$. In parallel, the $P B C_{\mathrm{Zn}}$ of the studied soil was determined by the laboratory method of ion exchange equilibrium under static conditions. The $P B C_{Z n}$ value was $150 \mathrm{mmol} \mathrm{kg}{ }^{-1}$. Thus, the values of the buffer capacity of soils in relation to a heavy metal $(\mathrm{Zn})$, determined by two methods, turned out to be of the same order. The relative difference was $15 \%$.

The considered methodological approach opened up opportunities for using data obtained during the agroecological monitoring of contaminated agricultural lands (such as the content of labile forms of $\mathrm{HMs}$, the exchange forms of macroelements ( $\mathrm{Ca}$ and $\mathrm{Mg}$ ) in soils, and the concentrations of $\mathrm{HMs}, \mathrm{Ca}$, and $\mathrm{Mg}$ in plants) to calculate the values of $P B C(V)_{\mathrm{HM}}$ of the studied soils. However, to do this, it is necessary to have a database of the concentration factors of these HMs and macroelements (such as $\mathrm{Ca}$ and $\mathrm{Mg}$ ) for various crops that are intended to be used as test plants. It is desirable that the composition of nutrient solutions be as close as possible to real soil solutions, at least at the level of soil types.

With the help of an original lysimetric installation of cyclic action and the use of a radioactive tracer ${ }^{65} \mathrm{Zn}$ applied to the studied Albic Retisol (Loamic, Ochric)soil, various aspects of the process of zinc migration and transformation of its forms in the soil-soil solution-plant system were studied. This allowed us to obtain a number of important parameters characterizing the lability and bioavailability of zinc in quasi-equilibrium conditions. Thus, for the studied soil with a known content of natural (stable) $\mathrm{Zn}$ and additionally introduced radionuclide ${ }^{65} \mathrm{Zn}$, the regularities of metal distribution between different soil forms were established by using sequential fractionation method.

It was established that the enrichment of labile chemical $\mathrm{Zn}$ fraction by the radioactive tracer ${ }^{65} \mathrm{Zn}\left(E F\left({ }^{65} \mathrm{Zn} / \mathrm{Zn}\right)\right.$ Fr.I was 1.54 times higher than the same value for the soil solution at the time corresponding to the beginning of the vegetation experiment. At the same time, the ratio of the remaining ("conditionally labile", "conditionally fixed", and "fixed") forms of stable $\mathrm{Zn}$ in the soil with ${ }^{65} \mathrm{Zn}$ was $0.19-0.82$ times lower than that of the soil solution. Based on the obtained value of $E F\left({ }^{65} \mathrm{Zn} / \mathrm{Zn}\right)_{\text {Fr.I }}$, we calculated the amount of the pool of labile " $E$-value" $\left(E_{Z n}\right)$ compounds of native zinc in the unit of the mass of the studied soil as: $E_{Z n} \cong C(Z n)$, Fr.I $=3.95 \pm 0.16 \mathrm{mg} \mathrm{kg}^{-1}$ (or $10.7 \pm 0.4 \%$ ). The corresponding specific activity value of ${ }^{65} \mathrm{Zn}\left(\mathrm{A}_{\mathrm{sp}}\left({ }^{65} \mathrm{Zn} / \mathrm{Zn}\right)_{\text {Fr.I }}\right)$ equaled $4660 \pm 830 \mathrm{~Bq} \mathrm{mg}{ }^{-1}$.

At the beginning of the vegetation experiment, we recorded a lower enrichment of native zinc contained in the quasi-equilibrium soil solution with ${ }^{65} \mathrm{Zn}$ (after balancing it with the soil for 1 year) compared to the stable zinc contained in Fraction I. This indicated the existence of a slow process of isotopic exchange between the mobile and other ("conditionally labile", "conditionally fixed", and "fixed") forms of zinc by means of the liquid phase of the studied soil-soil solution. Later, during the vegetation experiment, as a result of the vital activity of the plants, the soil solution was depleted with zinc and alkalinized, which led to an increase in the values of $\mathrm{A}_{\mathrm{sp}}\left({ }^{65} \mathrm{Zn} / \mathrm{Zn}\right)_{\text {soil solution }}$ to those close to $\mathrm{A}_{\mathrm{sp}}\left({ }^{65} \mathrm{Zn} / \mathrm{Zn}\right)$ Fr.I.

The dynamics of the transition to the soil solution phase and the parameters of the uptake of $\mathrm{Zn}\left({ }^{65} \mathrm{Zn}\right)$ by test plants were also evaluated. According to the results of the experiment, the total removal of natural $\mathrm{Zn}$ and radionuclide ${ }^{65} \mathrm{Zn}$ by plants (roots and vegetative parts) was calculated as a percentage of the total amount of $\mathrm{Zn}\left({ }^{65} \mathrm{Zn}\right)$ in the soil: $0.34(0.70) \%$. These data suggest that the removal of zinc from soil by plants is insignificant and had no noticeable effects on the ratio of the forms of the metal in the soil. 
Author Contributions: V.S.A. conceived and designed the experiments; V.S.A., L.N.A., and A.I.S. performed the experiments; V.S.A. analyzed the data; V.S.A., L.N.A., and A.I.S. contributed to manuscript preparation. All authors have read and agreed to the published version of the manuscript.

Funding: The study was carried out with the financial support of the Russian Foundation for Basic Research (RFBR Grant No. 19-29-05039).

Institutional Review Board Statement: Not applicable because no humans or animals were involved in our study.

Informed Consent Statement: Not applicable because no humans or animals were involved in our study.

Data Availability Statement: Data sharing is not applicable to this article.

Acknowledgments: The Russian Institute of Radiology and Agroecology (RIRAE) is highly acknowledged for providing access to the laboratory facilities needed for this study. We are grateful to Dikarev D.V., Frigidov R.A., Korneev Yu.N., Sarukhanov A.V., Tomson A.V., and Korovin S.V. for the help in conducting elemental and gamma spectrometric analyses.

Conflicts of Interest: The authors declare that they have no conflict of interest.

\section{Appendix A}
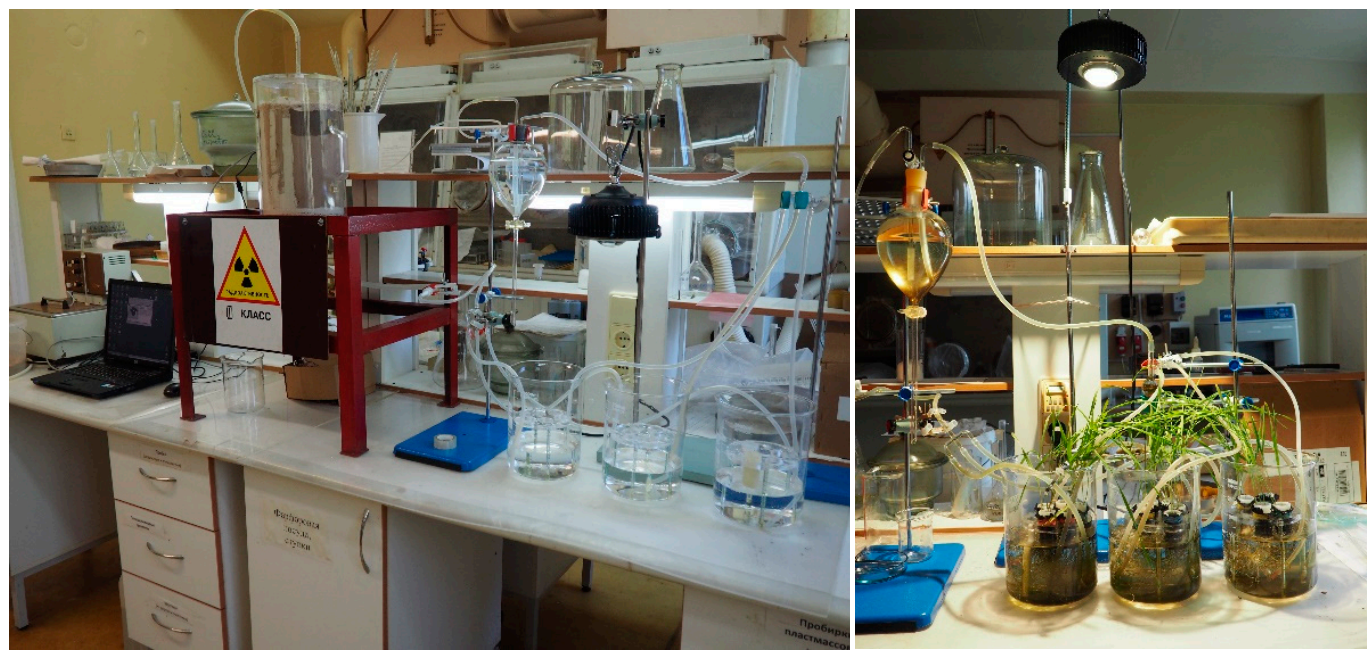

Figure A1. A stand for studying the parameters of ${ }^{65} \mathrm{Zn}(\mathrm{Zn})$ migration in the soil-soil solution-plant system: $1-$ the moment of equilibration of deionized water in the system with Albic Retisol (Loamic, Ochric) soil; 2-vegetative vessels with plants.

\section{References}

1. Pandey, R. Mineral Nutrition of Plants. In Plant Biology and Biotechnology. Volume I: Plant Diversity, Organization, Function and Improvement; Bahadur, B., Rajam, M.V., Sahijram, L., Krishnamurthy, K.V., Eds.; Springer: New Delhi, India, 2015 ; pp. $499-538$.

2. Hacisalihoglu, G. Zinc (Zn): The Last Nutrient in the Alphabet and Shedding Light on Zn Efficiency for the Future of Crop Production under Suboptimal Zn. Plants 2020, 9, 1471. [CrossRef] [PubMed]

3. Grusak, M.A.; DellaPenna, D. Improving the Nutrient Composition of Plants to Enhance Human Nutrition and Health. Annu. Rev. Plant Biol. 1999, 50, 133-161. [CrossRef] [PubMed]

4. Khadhar, S.; Sdiri, A.; Chekirben, A.; Azouzi, R.; Charef, A. Integration of sequential extraction, chemical analysis and statistical tools for the availability risk assessment of heavy metals in sludge amended soils. Environ. Pollut. 2020, 263, 114543. [CrossRef]

5. Alloway, B.J. Soil factors associated with zinc deficiency in crops and humans. Environ. Geochem. Health 2009, 31, 537-548. [CrossRef] [PubMed]

6. Hacisalihoglu, G.; Kochian, L. How do some plants tolerate low levels of soil zinc? Mechanisms of zinc efficiency in crop plants. New Phytol. 2003, 159, 341-350. [CrossRef]

7. Barber, S.A. Soil Nutrient Bioavailability: A Mechanistic Approach, 2nd ed.; John Wiley \& Sons: New York, NY, USA, $1995 ;$ p. 384.

8. Kabata-Pendias, A. Trace Elements in Soils and Plants; CRC Press: London, UK, 2011; p. 505. 
9. Liu, Y.; Gao, T.; Xia, Y.; Wang, Z.; Liu, C.; Li, S.; Wu, Q.; Qi, M.; Lv, Y. Using Zn isotopes to trace Zn sources and migration pathways in paddy soils around mining area. Environ. Pollut. 2020, 267, 115616. [CrossRef] [PubMed]

10. Nevidomskaya, D.G.; Minkina, T.M.; Soldatov, A.V.; Bauer, T.V.; Shuvaeva, V.A.; Zubavichus, Y.V.; Trigub, A.L.; Mandzhieva, S.S.; Dorovatovskii, P.V.; Popov, Y.V. Speciation of $\mathrm{Zn}$ and $\mathrm{Cu}$ in Technosol and evaluation of a sequential extraction procedure using XAS, XRD and SEM-EDX analyses. Environ. Geochem. Health 2021, 43, 2301-2315. [CrossRef]

11. Nazif, W.; Marzouk, E.; Perveen, S.; Crout, N.; Young, S. Zinc solubility and fractionation in cultivated calcareous soils irrigated with wastewater. Sci. Total Environ. 2015, 518-519, 310-319. [CrossRef]

12. Voegelin, A.; Tokpa, G.; Jacquat, O.; Barmettler, K.; Kretzschmar, R. Zinc Fractionation in Contaminated Soils by Sequential and Single Extractions: Influence of Soil Properties and Zinc Content. J. Environ. Qual. 2008, 37, 1190-1200. [CrossRef]

13. Adriano, D.C. Trace Elements in Terrestrial Environments; Springer: New York, NY, USA; Berlin/Heidelberg, Germany, 2001 ; p. 868

14. He, Q.; Ren, Y.; Mohamed, I.; Ali, M.; Hassan, W.; Zeng, F. Assessment of trace and heavy metal distribution by four sequential extraction procedures in a contaminated soil. Soil Water Res. 2013, 8, 71-76. [CrossRef]

15. Kersten, M.; Förstner, U. Chemical fractionation of heavy metals in anoxic estuarine and coastal sediments. Water Sci Technol. 1986, 18, 121-130. [CrossRef]

16. Ladonin, D.V. Fractional-Isotopic Composition of Lead Compounds in Soils of the Kologrivskii Forest Reserve. Eurasian Soil Sci. 2018, 51, 929-937. [CrossRef]

17. Ladonin, D.V. Heavy metal compounds in soils: Problems and methods of study. Eurasian Soil Sci. 2002, 35, 605-613.

18. Minkina, T.M.; Nevidomskaya, D.G.; Shuvaeva, V.A.; Soldatov, A.V.; Tsitsuashvili, V.S.; Zubavichus, Y.V.; Rajput, V.D.; Burachevskaya, M.V. Studying the transformation of $\mathrm{Cu}^{2+}$ ions in soils and mineral phases by the XRD, XANES, and sequential fractionation methods. J. Geochem. Explor. 2018, 184, 365-371. [CrossRef]

19. Minkina, T.M.; Mandzhieva, S.S.; Burachevskaya, M.V.; Bauer, T.; Sushkova, S.N. Method of determining loosely bound compounds of heavy metals in the soil. MethodsX 2018, 5, 217-226. [CrossRef] [PubMed]

20. Morabito, R. Extraction techniques in speciation analysis of environmental samples Fresenius. J. Anal. Chem. 1995, 351, 378-385.

21. Quevauviller, P. (Ed.) Methodologies in Soil and Sediment Fractionation Studies. Single and Sequential Extraction Procedures; Royal Society of Chemistry: Cambridge, UK, 2002; 180p.

22. Wali, A.; Colinet, G.; Ksibi, M. Speciation of Heavy Metals by Modified BCR Sequential Extraction in Soils Contaminated by Phosphogypsum in Sfax, Tunisia. Environ. Res. Eng. Manag. 2015, 70, 14-25. [CrossRef]

23. Young, S.; Zhang, H.; Tye, A.; Maxted, A.; Thums, C.; Thornton, I. Characterizing the availability of metals in contaminated soils. I. The solid phase: Sequential extraction and isotopic dilution. Soil Use Manag. 2005, 21, 450-458. [CrossRef]

24. Echevarria, G.; Morel, J.L.; Fardeau, J.C.; Leclerc-Cessac, E. Assessment of Phytoavailability of Nickel in Soils. J. Environ. Qual. 1998, 27, 1064-1070. [CrossRef]

25. Frossard, E.; Sinaj, S. The Isotope Exchange Kinetic Technique: A Method to Describe the Availability of Inorganic Nutrients. Applications to K, P, S and Zn. Isot. Environ. Health Stud. 1997, 33, 61-77. [CrossRef]

26. Garforth, J.M.; Bailey, E.H.; Tye, A.M.; Young, S.D.; Lofts, S. Using isotopic dilution to assess chemical extraction of labile Ni, Cu, $\mathrm{Zn}, \mathrm{Cd}$ and $\mathrm{Pb}$ in soils. Chemosphere 2016, 155, 534-541. [CrossRef]

27. Huang, Z.-Y.; Chen, T.; Yu, J.; Zeng, X.-C.; Huang, Y.-F. Labile Cd and Pb in vegetable-growing soils estimated with isotope dilution and chemical extractants. Geoderma 2011, 160, 400-407. [CrossRef]

28. Tongtavee, N.; Shiowatana, J.; McLaren, R.G.; Gray, C.W. Assessment of lead availability in contaminated soil using isotope dilution techniques. Sci. Total Environ. 2005, 348, 244-256. [CrossRef] [PubMed]

29. Nefedov, V.D.; Texter, E.N.; Toropova, M.A. Radiochemistry; Higher School: Moscow, Russia, 1987; p. 271. (In Russian)

30. Mandzhieva, S.S.; Minkina, T.M.; Motuzova, G.V.; Golovatyi, S.E.; Miroshnichenko, N.N.; Fateev, A.I.; Lukashenko, N.K. Fractional and group composition of zinc and lead compounds as an indicator of the environmental status of soils. Eurasian Soil Sci. 2014, 47, 511-518. [CrossRef]

31. Motuzova, G.V. Compounds of Microelements in Soils: Systemic Organization, Ecological Importance, Monitoring; Editoral URSS: Moscow, Russia, 1999; p. 168. (In Russian)

32. Zyrin, N.G.; Sadovnikova, L.K. Chemistry of Heavy Metals, Arsenic and Molybdenum in Soils; MSU Publication: Moscow, Russia, 1985; p. 208. (In Russian)

33. Dobrovolsky, V.V. Zinc and Cadmium in the Environment; Nauka: Moscow, Russia, 1992; p. 200. (In Russian)

34. Anisimov, V.S.; Anisimova, L.N.; Frigidova, L.M.; Dikarev, D.V.; Frigidov, R.A.; Korneev, Y.N.; Sanzharov, A.I.; Arysheva, S.P. Evaluation of the Migration Capacity of Zn in the Soil-Plant System. Eurasian Soil Sci. 2018, 51, 407-417. [CrossRef]

35. Baker, A.J.M. Accumulators and excluders-Strategies in the response of plants to heavy metals. J. Plant Nutr. 1981, 3, 643-654. [CrossRef]

36. Koolman, J.; Roehm, K.-H. Color Atlas of Biochemistry, 2nd ed.; Georg Thieme Verlag: Stuttgart, Germany; New York, NY, USA, $2005 ;$ p. 467.

37. Hacisalihoglu, G.; Hart, J.J.; Kochian, L. High- and Low-Affinity Zinc Transport Systems and Their Possible Role in Zinc Efficiency in Bread Wheat. Plant Physiol. 2001, 125, 456-463. [CrossRef]

38. Hart, J.J.; Norvell, W.A.; Welch, R.M.; Sullivan, L.A.; Kochian, L. Characterization of Zinc Uptake, Binding, and Translocation in Intact Seedlings of Bread and Durum Wheat Cultivars. Plant Physiol. 1998, 118, 219-226. [CrossRef] 
39. Pence, N.S.; Larsen, P.B.; Ebbs, S.; Letham, D.L.D.; Lasat, M.M.; Garvin, D.F.; Eide, D.; Kochian, L. The molecular physiology of heavy metal transport in the Zn/Cd hyperaccumulator Thlaspi caerulescens. Proc. Natl. Acad. Sci. USA 2000, 97, 4956-4960. [CrossRef] [PubMed]

40. Nye, P.H.; Tinker, P.B. Solute Movement in the Soil-Root System; Blackwell Scientific Publucations: Oxford, UK, $1977 ;$ p. 342.

41. Barbosa, B.C.F.; Silva, S.C.; de Oliveira, R.R.; Chalfun, A. Zinc supply impacts on the relative expression of a metallothionein-like gene in Coffea arabica plants. Plant Soil 2017, 411, 179-191. [CrossRef]

42. Cosio, C.; Martinoia, E.; Keller, C. Hyperaccumulation of Cadmium and Zinc in Thlaspi caerulescens and Arabidopsis halleri at the Leaf Cellular Level. Plant Physiol. 2004, 134, 716-725. [CrossRef]

43. Lin, Y.-F.; Aarts, M.G.M. The molecular mechanism of zinc and cadmium stress response in plants. Cell. Mol. Life Sci. 2012, 69, 3187-3206. [CrossRef]

44. Subhashini, V.; Swamy, A.V.V.S.; Krishna, R.H. Pot Experiment: To Study the Uptake of Zinc by Different Plant Species in Artificially Contaminated Soil. World J. Environ. Eng. 2013, 1, 27-33. [CrossRef]

45. Tiong, J.; McDonald, G.K.; Genc, Y.; Pedas, P.; Hayes, J.E.; Toubia, J.; Langridge, P.; Huang, C.Y. HvZIP 7 mediates zinc accumulation in barley (Hordeum vulgare) at moderately high zinc supply. New Phytol. 2014, 201, 131-143. [CrossRef]

46. Anisimov, V.S.; Sanzharova, N.I.; Anisimova, L.N.; Geras'kin, S.A.; Dikarev, D.V.; Frigidova, L.M.; Frigidov, R.A.; Belova, N.V. The assessment of the migration ability and phytotoxicity of $\mathrm{Zn}$ in the system soil-plant. Agrochemistry 2013, 1, 64-74. (In Russian)

47. Beckett, P.H.T. Studies on soil potassium II. The 'immediate' Q/I relations of labile potassium in the soil. J. Soil Sci. 1964, 15, 9-23. [CrossRef]

48. Sokolov, A.V. (Ed.) Agrochemical Methods of Soil Research; Nauka: Moscow, Russia, 1975; 656p. (In Russian)

49. Beckett, P. Potassium-Calcium Exchange Equilibria in Sois: Specific Adsorption Sites for Potassium. Soil Sci. 1964, 97, 376-383. [CrossRef]

50. Beckett, P.H.T.; Nafady, M.H.M. Potassium-Calcium exchange equilibria in soils: The location of non-specific (Gapon) and specific exchange sites. J. Soil Sci. 1967, 18, 263-281. [CrossRef]

51. Kruglov, S.V.; Anisimov, V.S.; Lavrent'eva, G.V.; Anisimova, L.N. Parameters of Selective Sorption of Co, Cu, Zn, and Cd by a Soddy-Podzolic Soil and a Chernozem. Eurasian Soil Sci. 2009, 42, 385-393. [CrossRef]

52. Pinsky, D.L. Ion exchange Processes in Soils; Pushchino, Russia, 1997; p. 166. (In Russian)

53. Sokolova, T.A.; Trofimov, S.Y. Sorption Properties of Soils. Adsorption. Cation Exchange: A Textbook on Some Chapters of Soil Chemistry; Grif and K: Tula, Russia, 2009; p. 172. (In Russian)

54. Blossfeld, S.; Perriguey, J.; Sterckeman, T.; Morel, J.-L.; Lösch, R. Rhizosphere pH dynamics in trace-metal-contaminated soils, monitored with planar pH optodes. Plant Soil 2010, 330, 173-184. [CrossRef]

55. Mineev, V.G. (Ed.) Practical Course on Agrochemistry; MSU Publication: Moscow, Russia, 2001; p. 689.

56. Arinushkina, E.V. Chemical Analysis of Soils and Soils; MSU Publication: Moscow, Russia, 1970; p. 480. (In Russian)

57. Sposito, G. The Chemistry of Soils, 2nd ed.; Oxford University Press Inc.: New York, NY, USA, 2008; p. 329.

58. Obukhov, A.I.; Plekhanova, I.O. Atomic Absorption Analysis in Soil-Biological Investigations; MSU Publication: Moscow, Russia, 1991; p. 184. (In Russian)

59. Dospekhov, B.A. Methodology of Field Experience (with the Basics of Statistical Processing of Research Results); Agropromizdat: Moscow, Russia, 1985; p. 351. (In Russian)

60. Prichard, E.; Barwick, V. Quality Assurance in Analytical Chemistry; Wiley: Hoboken, NJ, USA, 2007; p. 293.

61. James, G.; Witten, D.; Hastie, T.; Tibshirani, R. An Introduction to Statistical Learning; Springer: New York, NY, USA, $2013 ;$ p. 426. [CrossRef] 